The Effectiveness of Capital Adequacy Measures in Predicting Bank Distress 



\title{
THE EFFECTIVENESS OF Capital Adequacy Measures IN Predicting Bank Distress
}

\author{
Authors: \\ David G. Mayes and Hanno Stremmel
}

SUERF - The European Money and Finance Forum Vienna 2014

SUERF Study 2014/1

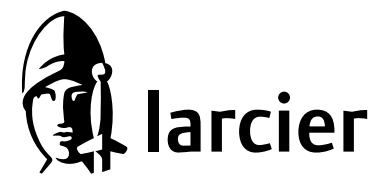


CIP

The Effectiveness of Capital Adequacy Measures in Predicting Bank Distress

Authors: David G. Mayes and Hanno Stremmel

Keywords: Bank Failure, Basel III, CAMELS, Early Warning System, Leverage Ratio, Risk-Based Capital, Regulation

JEL Codes: G01, G21, G28, G33

Vienna: SUERF (SUERF Studies: 2014/1) - March 2014

ISBN: 978-3-902109-72-9

\section{(C) 2014 SUERF, Vienna}

Copyright reserved. Subject to the exception provided for by law, no part of this publication may be reproduced and/or published in print, by photocopying, on microfilm or in any other way without the written consent of the copyright holder(s); the same applies to whole or partial adaptations. The publisher retains the sole right to collect from third parties fees payable in respect of copying and/or take legal or other action for this purpose. 


\section{TABLE OF CONTENTS}

The Effectiveness of Capital Adequacy Measures in Predicting

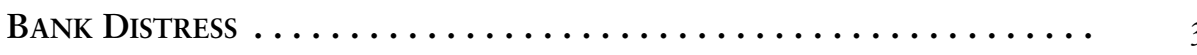

David G Mayes and Hanno Stremmel

Introduction. $\ldots \ldots \ldots \ldots \ldots \ldots \ldots \ldots \ldots \ldots \ldots \ldots \ldots \ldots \ldots \ldots \ldots$

1. Previous Evidence $\ldots \ldots \ldots \ldots \ldots \ldots \ldots \ldots \ldots \ldots \ldots \ldots$

1.1. Early Warning Systems ................... 6

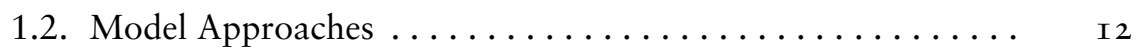

1.2.1. Statistical estimation techniques ........... I 2

1.2.2. Non-parametric and distribution-free estimation techniques....................... I5

1.3. The Choice of Determining the CAMELS Components..... I6

1.4. Relevant Recent Experience from CAMELS-related Studies .. 20

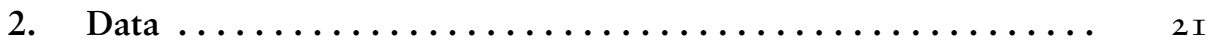

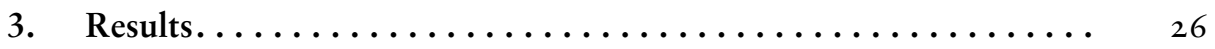

4. Prediction Accuracy and Forecasting Ability ........... 30

5. Test of Robustness $\ldots \ldots \ldots \ldots \ldots \ldots \ldots \ldots \ldots \ldots \ldots \ldots \ldots \ldots \ldots$

6. Conclusion and Policy Implications.............. 43

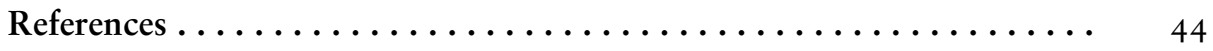

SUERF - Société Universitaire Européenne de Recherches Financières .. 53

SUERF Studies........................... 53 



\title{
The EFFeCtiveness of CAPITAL Adequacy Measures in Predicting Bank Distress
}

\author{
David G Mayes and Hanno Stremmel ${ }^{1}$
}

\begin{abstract}
Our concern in this paper is two-fold: first to see whether the determinants of bank distress and failure have been any different in the GFC from previous years: second to see whether simple measures of capital adequacy outperform their risk-weighted counterparts as predictors, despite the focus on the later in the Basel framework. This paper examines bank distress within a large quarterly data set of FDIC-insured US banks from 1992 to 2012. We contrast the effects of risk-weighted and non-risk-weighted capital measures for various banking types using two estimation methods (logit and discrete survival time analysis). We predict bank failures and draw inferences about the stability of contributing bank characteristics. Our models incorporate CAMELS indicators that consider the bank-specific variables and macroeconomic conditions. We find that the non-risk-weighted capital measure, the adjusted leverage ratio, explains bank distress and failures best with considerable accuracy. Further, we find that the influence of the characteristics in the two methods differs only slightly. Also the characteristics of banks getting into bank distress are alike over time. That means that the familiar banking characteristics for identifying a distress-prone bank identified fragile banks effectively during the global crisis without new information and are likely to continue to work well in the future. Further, our findings suggest that the more complex a bank is the more effective is the leverage ratio compared to the risk-based capital ratio $^{2}$.
\end{abstract}

\section{INTRODUCTION}

During the global financial crisis (GFC), authorities in many countries appeared to be surprised, not just by the number of banks that failed, but also by which banks failed. We investigate two obvious reasons why this might have occurred. The first is that the GFC represented a substantial change in behaviour and hence

\footnotetext{
David G Mayes, Professor of Banking and Financial Institutions, University of Auckland, New Zealand, e-mail: d.mayes@auckland.ac.nz.

Hanno Stremmel, Department of Economics, WHU - Otto Beisheim School of Management, Germany, e-mail: hanno.stremmel@whu.edu.

2 Acknowledgements: The authors are very grateful to Jonathan Batten, Ralf Fendel, Jack Riedhill and seminar participants at Deutsche Bundesbank and University of Auckland. We also thank the participants at the "Stability and efficiency in financial systems" conference at the Reserve Bank of New Zealand in Wellington, the "XXI International Conference on Money, Banking and Finance" in Rome, the "Campus for Finance Research Conference 2013" in Vallendar, the "6th RGS Doctoral Conference in Economics" in Bochum, the "10th Biennial Pacific Rim Conference - Western Economic Association International" in Tokyo, the "4th Conference on Financial Markets and Corporate Governance" in Wellington, the "5th IFABS 2013 Conference" in Nottingham, the "88th Annual Conference - Western Economic Association International" in Seattle, and the "28th Annual Congress of the European Economic Association" in Gothenburg.
} 
traditional early warning systems (EWS) of bank failure estimated on the basis of previous experience could not be expected to work well. The second is that the key indicator of bank weakness, capital adequacy, may not have functioned as well as it might because the risk-weighted measures that lie at the heart of the Basel system are not the best predictor available.

In this paper we investigate these two questions using a comprehensive quarterly database on individual banks over the period 1992 to the end of 2012, available from the FDIC for the US. This enables us to go further than other studies and estimate EWS models over a long enough period before the GFC that it includes sufficient failures to get a well-determined model. We can then see both how well this predicts and how much the determinants of the failures during the GFC differ from those over the previous period. Second, we investigate the performance of different measures of capital adequacy, in particular contrasting the normal risk-weighted ratios with a simple leverage ratio. This helps to fill an important gap in the findings of the existing literature.

To preview the outcome, we find that models based on previous information do work quite well and that while the determinants of failure do change during the GFC they are not sufficient to explain poor prediction. We also find that the leverage ratio does seem to perform a little better than risk-weighted capital. These findings have important policy implications, as supervisors with access to confidential data should be able to make better predictions than we able to with only the published information. They also lend support to Basel III, which, in its efforts to provide comprehensive capital buffers against losses in banks, has added a leverage ratio to the revised risk-weighted buffers that characterised both Basel I and Basel II (Basel Committee on Banking Supervision (BCBS), 2011).

Some countries, Australia and New Zealand among them, have announced that they do not plan to introduce the leverage ratio (Australian Prudential Regulation Authority (APRA), 2012; Reserve Bank of New Zealand (RBNZ), 2011) They argue inter alia that the leverage ratio is a crude measure and at the value chosen will not add anything useful to more sophisticated measures and might impose an unnecessary cost on the banks. Others promote a diametrically opposed view, that if any capital buffer is to be used it should be a leverage ratio, preferably one that catches off-balance sheet activity (Joint Shadow Financial Regulatory Committee (JSFR), 2011; Shadow Financial Regulatory Committee (SFRC), 2012). The main argument advanced is that not only is leverage typically what leads to fragility in banks but that it is readily observed and difficult to evade if equity is measured properly. In other words, its advantage is in its crudeness. The arguments of this camp have been greatly strengthened by Haldane's presentation to the 2012 Jackson Hole Conference (Haldane and Madouros, 2012), where he 
argues that simple rules such as the leverage ratio work better as indicators of problems, based on a subset of the data we use here ${ }^{3}$. As Haldane (2011) previously stated 'complex systems typically call for simple control rules'.

There is also some empirical evidence that simple leverage ratios are better indicators of potential bank distress (Estrella et al., 2000). However, there is clear empirical evidence from the global financial crisis (GFC) and earlier that risk-weighted capital buffers were not good predictors in practice. Hau et al. (2012) argue that "Basel risk-weights applied to claims on institutions do not reflect underlying relative risk." Northern Rock for example was fully compliant with risk-weighted measures shortly before its failure (Mayes and Wood, 2009). Its leverage ratio was however extreme and would not have met the Basel III criterion (Shin, 2009). Nevertheless, it could be that much of the problems with banks in the GFC was as a result of authorities not reacting to signs of danger, rather than the danger signs not being present. Using evidence from the Material Loss Reviews, Garcia (2012), for example, points out that supervisors in the US missed the normal 'red flags'. Hence it was not the flags which were at fault.

We had originally hoped to undertake this analysis using European data but there is nothing comparable to the US information available. Betz et al. (2013) have managed to put together a limited but workable data set for 298 EU banks over various parts of the period 2000-2013. We have obtained some limited results using similar information but without comparable results ${ }^{4}$.

The remainder of the paper is organized as follows. We begin by surveying the evidence from the existing literature both across countries and types of banks and across the different parametric and non-parametric methods that have been used (Section 1). In the light of this we use both a logit approach and a survival (hazard) approach to check for robustness. Section 2 considers the characteristics of the data we use from the FDIC, while Section 3 sets out the main results from the estimation of both models. Since the main point of this exercise is to explore the forecasting ability of these models, this is the subject of Section 4. Section 5 contains a set of robustness tests to see if the model is stable and the degree to which it suffers from omitted variables. Section 6 offers some conclusions and policy implications.

\footnotetext{
On the basis of an international dataset, Mariathasan and Merrouche (2012) also support this position, when they argue that there is evidence that more fragile banks tend to manipulate risk-weighted measures, thereby helping to obscure their true position from both the authorities and their current and potential creditors, when the bank is under threat. Hence while risk-weighted measures may be better indicators in normal times they perform worse than the simple leverage ratio once problems appear on the horizon.

4 The data problems are horrific and we have only managed to obtain matched data for a small number of recent years from publicly available sources for a few of the EU countries and with no M measure under CAMELS. Only capital adequacy acts as a good predictor. These results are therefore not reported. Clearly supervisory authorities with access to confidential data will be able to construct EWS where we cannot.
} 


\section{Previous EVIDENCE}

We begin by a meta-analysis of previous work on the subject, which is summarised in Table 1, in order to determine the most plausible approaches to use and the variables to include. We are concerned for our approach to be robust to a variety of methods and not dependent on a single model, so as to increase the generalisability of the conclusions.

\subsection{Early Warning Systems}

Over recent decades, a considerable literature has been devoted to explaining financial distress and failure of financial institutions, especially banks. Due to the uniqueness of banks and their potential fragility, determining which banks are likely to default or experience distress is a long-standing but still important concern. First, the findings assist banking supervisors and regulators in their task of maintaining a prudent and stable system. Second, the early detection of potential problems is likely to help reduce the expected cost of a bank failure and to decrease the chance of the problem spreading more widely through the financial system. If the characteristics of potential distress can be identified, this helps the authorities to focus their limited resources. To be useful the predictions need to be sufficiently accurate to avoid wasting too much time on sound banks, while also avoiding missing too many problem cases. Since most banking regulatory and supervisory authorities employ such early warning systems (EWS), apparently they find them sufficiently useful ${ }^{5,6}$. Nevertheless, there is considerable scope for improvement as the number of surprise failures in the global financial crisis suggests.

In the late 1970s the Federal Deposit Insurance Cooperation (FDIC) in the US developed and implemented an EWS to assess the financial, managerial, and operational strength and weaknesses of financial institutions. Its quality and success is demonstrated by the fact that this model provides the framework for empirical research on the topic and for most systems implemented in other countries. The EWS is characterised by a set of ratios obtained from financial statements (although not all the information is publicly available). These ratios are classified into six categories: capital adequacy (C), asset quality (A), management competence and expertise $(\mathrm{M})$, earning ability and strength $(\mathrm{E})$,

\footnotetext{
For an extended review on this use of EWS see Evens et al. (2000).

The FDIC does not use an EWS in quite the form we discuss it here (Collier et al., 2003). Its primary identification of potential problems comes from its on-site investigations that result in the CAMELS ratings that are discussed below. This is augmented each quarter by an off-site financial indicator model called SCOR, which tries to identify any bank with a satisfactory CAMELS rating that might be moving into difficulty and hence requires close attention. Predicting failure per se is not the key concern but being able to implement Prompt Corrective Action early while the bank is still recoverable. Once under close supervision, the FDIC has far more detailed information to hand than just the financial indicators.
} 


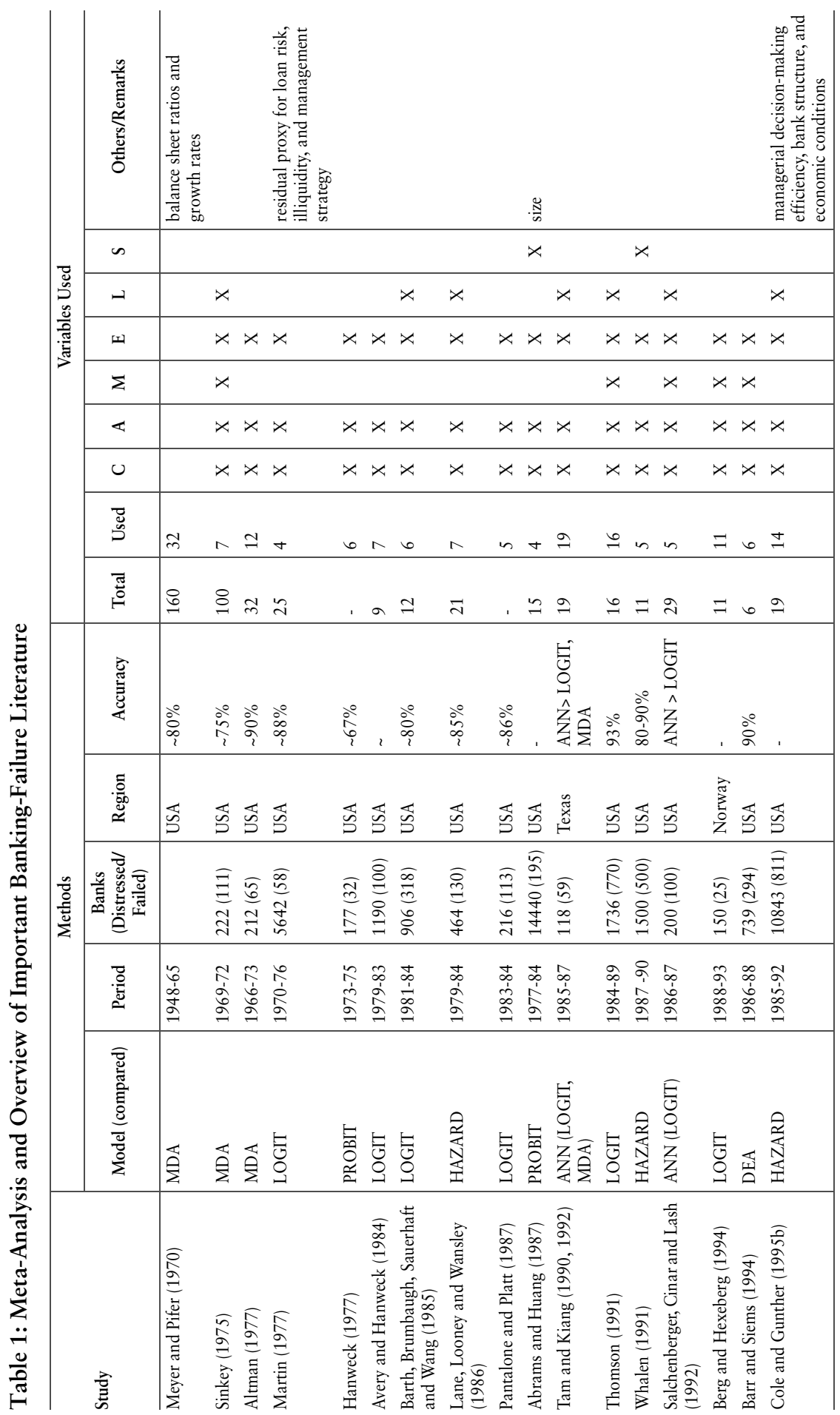




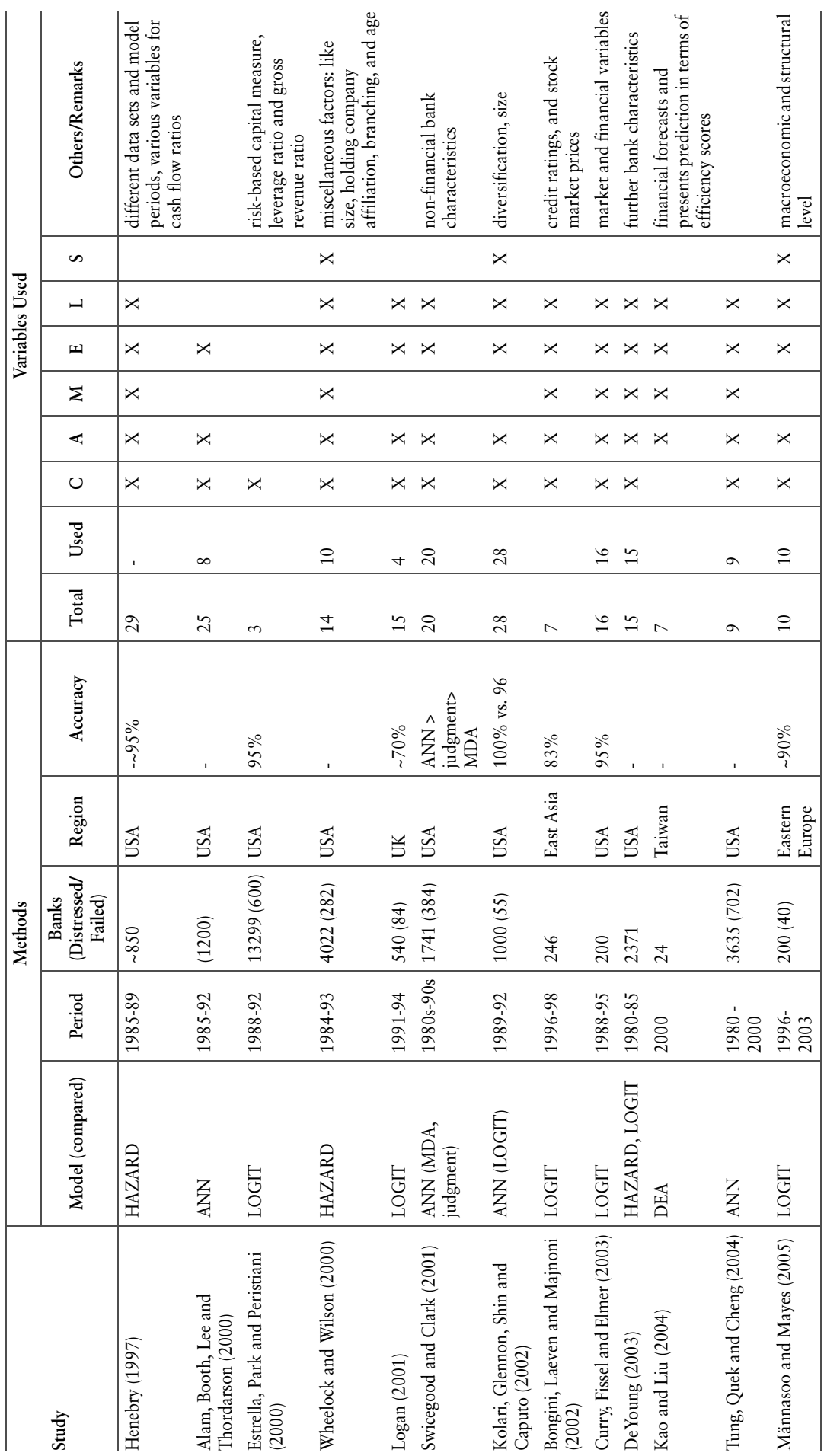




\begin{tabular}{|c|c|c|c|c|c|c|c|c|c|c|c|c|}
\hline \multirow{9}{*}{ 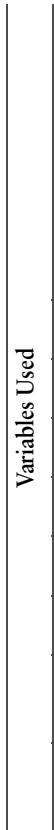 } & 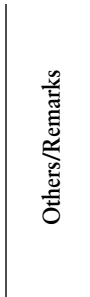 & 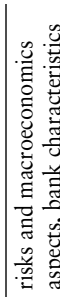 & 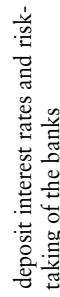 & & 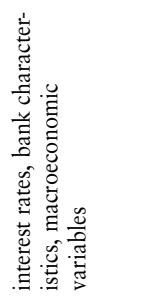 & 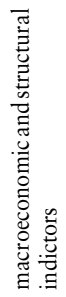 & 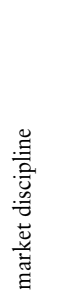 & 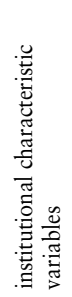 & 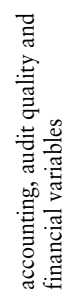 & 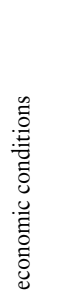 & 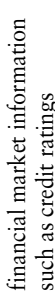 & \\
\hline & is & & & & & $x$ & & & & & $x$ & \\
\hline & - & & $x$ & $x$ & $x$ & $x$ & $x$ & & & $x$ & $x$ & $x$ \\
\hline & 피 & $x$ & $x$ & $x$ & $x$ & $x$ & $x$ & $x$ & & $x$ & $x$ & $x$ \\
\hline & $\Sigma$ & $x$ & $x$ & $x$ & $x$ & & $x$ & & & $x$ & $x$ & $x$ \\
\hline & $\varangle$ & $x$ & $x$ & $x$ & $x$ & $x$ & $x$ & $x$ & $x$ & $x$ & $x$ & $x$ \\
\hline & $u$ & $x$ & $x$ & $x$ & $x$ & $x$ & $x$ & $x$ & $x$ & $x$ & $x$ & $x$ \\
\hline & $\begin{array}{l}\bar{\Xi} \\
\stackrel{D}{D}\end{array}$ & in & $\wedge$ & $\hat{\sim}$ & $a$ & $\tilde{\sim}$ & $=$ & $a$ & $\therefore$ & $\underset{\infty}{\stackrel{0}{0}}$ & & \pm \\
\hline & 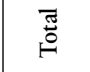 & in & 오 & $\hat{\sim}$ & $\Xi$ & $\tilde{\sim}$ & $\exists$ & $a$ & $\simeq$ & $\underset{\infty}{\stackrel{a}{(}}$ & $a$ & \pm \\
\hline \multirow{5}{*}{ 造 } & 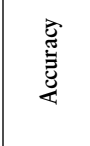 & 웅 & $\begin{array}{l}\stackrel{0}{0} \\
\substack{\infty \\
i}\end{array}$ & & 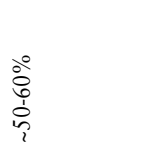 & $\stackrel{\circ}{\circ}$ & 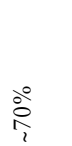 & 仓ें & $\stackrel{\circ}{\stackrel{2}{i}}$ & 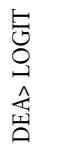 & . & ํํํ. \\
\hline & 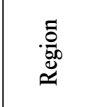 & 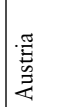 & $\begin{array}{l}\text { 萢 } \\
\stackrel{0}{0}\end{array}$ & & 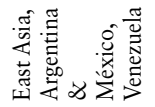 & 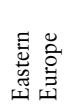 & 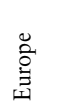 & 范 & 趈 & 艿 & 㟧 & 丞 \\
\hline & 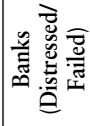 & $\stackrel{\circ}{2}$ & $\begin{array}{l}\widehat{E} \\
\stackrel{a}{a}\end{array}$ & $\frac{\infty}{0}$ & $\begin{array}{l}\sqrt{5} \\
\stackrel{\sqrt{3}}{\sqrt{6}} \\
\text { }\end{array}$ & $\begin{array}{l}\text { o } \\
\text { 文 } \\
\stackrel{8}{0}\end{array}$ & 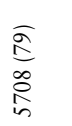 & $\begin{array}{l}\frac{a}{3} \\
\text { d } \\
\text { o } \\
\text { in }\end{array}$ & 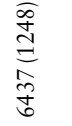 & 尽 & $\begin{array}{l}\widehat{\vec{c}} \\
\stackrel{0}{\circ} \\
\approx\end{array}$ & 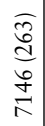 \\
\hline & 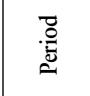 & م்َ & よ่ & 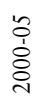 & 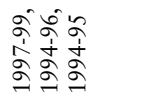 & 完志 & 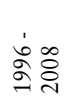 & 定 & 商 & 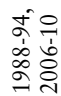 & $\begin{array}{l}\text { oे } \\
\text { +े } \\
\text { ठे }\end{array}$ & 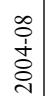 \\
\hline & 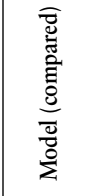 & 帠 & 氕 & 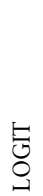 & 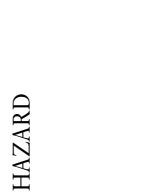 & 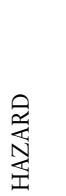 & $\underset{్}{~}$ & 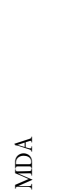 & ్ㅓㅇ & 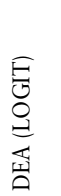 & 접 & 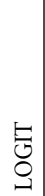 \\
\hline & $\bar{E}$ & 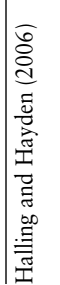 & 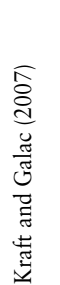 & 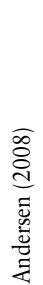 & 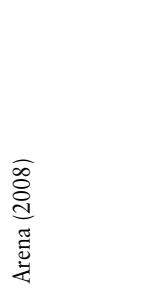 & 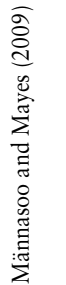 & 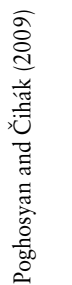 & 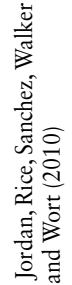 & 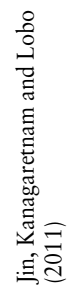 & 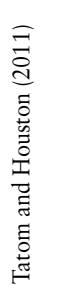 & 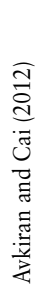 & 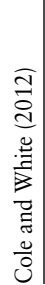 \\
\hline
\end{tabular}


liquidity $(\mathrm{L})$ and sensitivity to market risk $(\mathrm{S})$, jointly referred as $\operatorname{CAMEL}(\mathrm{S})^{7}$. For each component the regulatory authority assigned a rating using a scale from 1 (good) to 5 (bad), where ratings of 1 or 2 are considered to present no or little supervisory concern and ratings of 3-5 are the subject of moderate to major concern. These individual scores are combined to provide an overall rating also with a scale from 1 to 5 . An overall rating of 3 to 5 alerts the supervisors and the bank could face intervention by them ${ }^{8}$. CAMELS-ratings prepared by the FDIC are not public. The CAMEL(S) rating framework has its problems. Hanc (1998) points out that the majority of the banks that were marked as troubled actually did not fail, since the ratings triggered supervisory responses that prevented the failure. However, we use the categories of variables underlying the CAMELS framework as we do not have access to the CAMELS ratings themselves. The development and the implementation of similar EWS in Europe took until the early 1990s and a substantial number of EWS have now been developed round the world.

In recent years considerable effort has gone into improving EWS - starting well before the global financial crisis. While the generality of experience relating to failures may not change over the time, models and techniques have changed. The models used have been much better at explaining failures within the data set in their estimation than they have been at predicting new and as then unobserved failures. The ratios as well as the weighting of the individual indicators changed over the time. Behaviour by banks is likely to have a degree of endogeneity. Once banks understand how their fragility is being assessed they have a strong incentive to meet the criteria laid down while still pursuing their original strategies as far as they can $^{9}$. This change in their behaviour will make the prediction methods less effective and hence the EWS will need to be enhanced. If the components of the early warning systems have changed over the time and these changes provoke adjustments to models, there will be no general model that performs well in predicting failures and distress over a long time period. Although every distress or failure period is different, most are characterised by some patterns. The goal of the models is mostly to find these patterns and to enable accurate prediction of bankruptcy. Prediction models have become more sophisticated over time and more complex and interdisciplinary. As a result models are becoming more difficult to interpret - going beyond their private usefulness in the view of Haldane and Madouros (2012).

\footnotetext{
Until 1996 the component sensivity to market risk (S) was not included in the model, so it was then referred to as the CAMEL system. For more information see Flannery (1998) and Jose (1999).

For detail information on the functioning of the rating approach see Cole and Gunther (1995a).

Mariathasan and Merrouche (2012) suggest that banks in trouble systematically try to massage their key ratios so that they obscure the true extent of their difficulties.
} 
It is not surprising that absolute levels of risk may have been underestimated in the run up to the global financial crisis. It is always difficult to decide how much any upturn reflects enduring changes and how much simply a cyclical improvement that will disappear in due course. Natural optimism might suggest an upward bias but Hau et al. (2012) suggest that rating agencies have a relative bias as well. The same conflicts of interest that may contribute to this bias do not apply to the authorities. Nevertheless it is likely that large institutions with any given degree of fragility are more likely to be able to persuade the authorities of their probity than their smaller counterparts, if only because they can afford better communicators and prima facie are more diversified. Thus ordinal as well as cardinal ratings of possible default are countercyclical according to Hau et al.'s analysis of 369 banks in the US and the EU15 (i.e. prior to the 'eastern' enlargement).

Over the years a wide variety of early warning systems have been developed. There are two main dimensions to these EWS

(i) the institutions and the markets they cover;

(ii) the variables they include and the different channels of transmission they identify.

The early EWS mainly focused on individual banks and were concerned with individual banking failures, but there are other EWS that consider the soundness of the whole banking or financial sector and try to predict systemic crises ${ }^{10}$. This paper deals only with the individual banking level, where most models are of the CAMEL(S) variety. However, EWS at the financial sector level do often have important findings that are relevant for bank level studies ${ }^{11}$.

The original CAMEL model focuses on accounting and financial data for individual banks ${ }^{12}$. Some authors also added macroeconomic data to capture economic pressures and shocks that could trigger a banking failure or to cover divergence in cross country studies. Variables such as GDP growth, inflation, inter-bank interest rates or exchange rates are included to capture those effects ${ }^{13}$. (The final column of Table 1 lists these extra variables for each study.) There is also a strand of literature that uses market data and information. Flannery (1998) was probably the first to add market information, driven by market forces and discipline, including price-based indicators such as market expectations through

10 We focus here only on models that have been published and rely on publicly available data. Supervisors' internal models, particularly those making use of confidential information cannot, by their nature, be included.

11 Davis and Karim (2008), Demirgüç-Kunt and Detragiache (1998), Gaytán and Johnson (2002), GonzalezHermosillo (1999), and Hardy and Pazarbasioglu (1998) offer excellent reviews of these early warning systems for banking crises.

12 For instance, this model type is employed by Avery and Hanweck (1984), Cole and Gunther (1995b), Cole and Gunther (1998), Estrella et al. (2000), DeYoung (2003), Martin (1977), Whalen (1991), and Wheelock and Wilson (2000).

13 For implementation of macroeconomic or structural variables see Arena (2008), Halling and Hayden (2006) and Männasoo and Mayes (2005, 2009). 
stock prices, volatility of returns and bond spreads ${ }^{14}$. Market information-based approaches are only applicable for publicly listed and traded banks. However, in most countries the majority of financial institutions are not publicly traded, although the majority by value of deposits are. There are other non-accounting or market information indicators and information that can be taken into account instead, such as rating agency assessments. The idea is to capture the effects of risk and financial strength that are reflected in other indicators ${ }^{15}$. There are indicators of depositor behaviour and bank credit ratings of ratings agencies for example.

\subsection{Model Approaches}

We begin our meta-analysis (Table 1) by classifying the estimation methods, shown in column 2 of the table. Predominantly, models have used financial statements as their data source ${ }^{16}$. Only two main groups of failure and distress prediction methods: statistical and non-parametric techniques, seem to have been used $^{17}$. Although there is no single agreed definition of what constitutes failure or distress nor of the indicators to be used for it, which include insolvency, incidence of intervention or closure and assisted merger or acquisition. Hence comparison of models can readily neglect their detail.

\subsubsection{Statistical estimation techniques}

Statistical estimation techniques are the most widely used approach with discriminant analysis (DA) and logit/probit estimation being most common for cross-sectional methods. DA was the leading method originally. The idea is to model the dependent score variable for failures/distress as a function of input factors. A score is derived from a linear combination of independent predictive variables for each firm. Based on the sample, a cut-off point is defined so that banks with a score below the cut-off are expected to be in distress and accordingly the firms with a score above the cut-off are expected not to be in distress. This implies that input factors such the number of bad loans will be significantly different between failing and non-failing firms. However, discriminant allows more than just binary outcomes and can be extended to quadratic and multivariate discriminant analysis (MDA). This analysis combines linearly

14 See Bongini et al. (2002), Campbell et al. (2008), Čihák (2007), Curry et al. (2003), Curry et al. (2007), Hillegeist et al. (2004), Jagtiani and Lemieux (2001) and Pettway (1980) for an application of these approach.

15 See Kraft and Galac (2007), Poghosyan and Čihák (2009) and Avkiran and Cai (2012) for implementation of market information-based approaches.

16 For a detailed review of various techniques see Aziz and Dar (2006), Demirgüç-Kunt (1989), Demyanyk and Hasan (2010), Fethi and Pasiouras (2009), Ravi Kumar and Ravi (2007) and Tatom and Houston (2011).

17 Models sometimes use a combination of techniques, so that the classification is always not clear cut. 
multiple discriminant characteristics and variables within one model. The score of a (M)DA can be set out as follows:

$F_{i}=a_{0}+b_{1} x_{1}+b_{2} x_{2}+\ldots+b_{n} x_{n}$,

where $F_{i}$ is the failure score for a given institution $i, a_{0}$ is the intercept, $b_{i}$ are regression coefficients and $x_{i}$ are the characteristics. However, DA studies are no longer normally used. One major drawback was the restrictive assumptions of normally distributed regressors and the covariance matrices of the groups having to be identical. In any case multiple discriminant analysis is really only about classifying firms and not about estimating the risk of defaults (Eisenbeis, 1977). Furthermore, there are questions about the reliability of the discriminant analysis due to the restrictions of the model (Ohlson, 1980).

These critiques led to the emergence and increasing use of an alternative statistical approach, limited dependent variable models. These binary models apply a linear regression technique to estimate the probability that a particular outcome such as a bank failure occurs:

$D_{i}=\left\{\begin{array}{l}1 \text { if bank } i \text { fails } \\ 0 \text { otherwise }\end{array}\right.$.

These methods take a number of forms. The simplest is the linear probability model. The linear probability model determines the individual score or outcome for each dependent variable $D_{i}$ :

$D_{i}=X_{i} \beta_{i}+u_{i}$,

where $X_{i}$ reflects the given set of individual characteristics for observation $i, \beta_{i}{ }^{\prime}$ represents the vector of coefficients and $u_{i}$ is the disturbance term. The probability $P_{i}$ that a failure event occurs for observation $i$ is given by:

$P_{i}=\operatorname{Pr}\left(D_{i}=1\right)=X_{i} \beta_{i}+u_{i}$.

The coefficients obtained have to be interpreted in terms of probability. In addition to other shortcomings, this model formulation has the dominating disadvantage of assuming a normal distribution and not ensuring that the values obtained lie between zero and one, which is necessary for probability estimates.

Two other approaches, probit and logit models, can overcome this shortcoming and provide a transformation of the regression function ensuring that probability values are between zero and one. These employ statistical estimation methods such as maximum likelihood that are much more flexible than simple linear estimation techniques. The probit and logit models differ only in their assumed distribution. In both models the outcome probability is very sensitive to changes 
in variables. The logit model assumes a logistic distribution. Equation (3) is transformed into a logit function $F_{i}$. The general logit model and its given cumulative probability distribution are given by the following expressions:

$$
\begin{aligned}
& F_{i}=\frac{e^{D_{i}}}{1+e^{D_{i}}}=\frac{1}{1+e^{-D_{i}}} \\
& F_{i}\left(D_{i}\right)=F\left(X_{i} \beta_{i}{ }^{\prime}+u_{i}\right)=\frac{1}{1+e^{-D_{i}}} .
\end{aligned}
$$

The probit model on the other hand assumes a standardized normal distribution. Equation (3) can also be transformed into a cumulative standard normal function:

$F_{i}=\Phi\left(D_{i}\right)=\int_{-\infty}^{z_{i}} \frac{1}{\sqrt{2 \pi}} e^{\left(\frac{-D_{i}^{2}}{2}\right)} d D_{i}$

$F_{i}\left(D_{i}\right)=F\left(X_{i} \beta_{i}{ }^{\prime}+u_{i}\right)=\int_{-\infty}^{z_{i}} \frac{1}{\sqrt{2 \pi}} e^{\left(\frac{-z_{i}{ }^{2}}{2}\right)} d D_{i}$.

This ensures that the estimated probability lies between zero and one.

There is also another statistical technique that focuses on the time series dimension of failures: survival time analysis. The idea is not just to estimate the chance of failure by a bank but also to determinate the specific time period when it occurs and to investigate the change in probability of a failure over the time. There is a wide variety of different approaches. For banking failure the Cox (1972) proportional hazard model had dominated. This model, popularized by Kiefer (1988), applies parametric and non-parametric input factors and models the time of failure as the dependent variable. In a proportional hazards model the dependent variable is the time until failure $T_{i}$. The survivor function $S_{i}(t)$ represents the probability of surviving longer than $t$ periods and has the following form:

$S_{i}(t)=\operatorname{Pr}\left(T_{i}>t\right)=1-F_{t}$,

where $F_{t}$ represent the cumulative distribution function of the random variables $t$, which is the number of survived periods. The general form of the hazard function can be described as the limit of the condition probability that indicates the propensity to fail:

$$
h_{i}(t)=\lim _{d t \rightarrow 0} \frac{\operatorname{Pr}\left(t<T_{i}<t+d t \mid t \leq T_{i}\right)}{d t}=\frac{S_{i}^{\prime}(t)}{S(t)} .
$$


This formulation represents the failure probability at a given time period conditional on the observation has survived to period $t$.

The formulation of the Cox (1972) proportional hazard model is the following:

$h_{i}\left(t \mid X_{i} \beta_{i}{ }^{\prime}\right)=h_{0, t} \exp \left(X_{i} \beta_{i}{ }^{\prime}\right)$,

where is $h_{0, t}$ is the baseline hazard and $\beta_{i}$ is the vector of unknown regression coefficients.

\subsubsection{Non-parametric and distribution-free estimation techniques}

The two most popular ideas in this field are the artificial neural network (ANN) and data envelopment analysis (DEA). Artificial neural networks have been used to model banking failures since the beginning of the 1990s. In contrast to statistical approaches, this non-linear approach is able to capture non-linear effects such as the saturation effects. But these models need a large range of input data to perform well and have problems with extreme observations which is the major drawback of the method. Use of the ANN idea goes back to McCulloch and Pitts (1943). The way it works is inspired by the biological nervous system. Odom and Sharda (1990) are among the first to employ ANN for bankruptcy studies. They conclude that this technique outperformed multiple discriminant analysis by using the same variables. The basic computational structure of an ANN is based on three layers: input, hidden and output. The ANN tries to capture the connections of these layers. This system needs to learn patterns from available training data (in-sample) sets to perform in the total sample data well. Although no assumptions are imposed on the form of input/output functions or the need of continuous and differentiable form, the following formulation is used to model ANN (Tam and Kiang, 1992):

$$
\begin{aligned}
& I_{i}=\sum w_{i j} O_{j}+\phi_{i} \\
& O_{i}=\frac{1}{1+e^{I_{i}}},
\end{aligned}
$$

where $I_{i}$ is the input of $i, O_{i}$ is the output of $i, w_{i j}$ is the connection weighted between the $i$ and $j$, and $\phi_{i}$ is the bias of $i$.

Data envelopment analysis (DEA) aims at determining production efficiency by transforming a given input factor into given output factors by linear programming techniques. Due to the non-parametric approach, there is no equation that describes the relationship between the input and output factors. DEA is often used for banking benchmarking purposes and only rarely to predict banking failures. An exception is Avkiran and Cai (2012), who show in a multidimensional environment that it is the least 'efficient' banks that fail. 
Given this wide range of potential estimation techniques for predicting banking failures that have been used in practice, we use the two approaches that have been followed most widely in recent years, logit and time survival analysis, in our analysis in order to ensure the maximum of comparability with earlier work. This also enables us to encompass a wide range of the previous research. These two techniques also have the advantage of simplicity, comprehensibility and manageability in estimation. Our choice also reflects the finding that these approaches seem to be most appropriate when handling large data sets both in terms of number of determining factors and numbers of banks. However, these methods do have well-known problems. The logit model results are relative sensitive to variable choice. The survival time analysis technique has an issue with extreme events. But exactly these events often determine bank failure. This problem could be addressed by data transformation. The hazard model is also not able to differentiate between different failure processes from the same population. However, this problem should be limited with an increasing number of observations.

There is considerable appeal in the non-parametric and distribution-free estimation techniques such as neural networks or DEA as these studies have introduced degrees of complexity and sophistication to modelling failures. However the benefit of this complexity in the present context is of mixed value, since the model accuracy does not improve significantly. These new model types also have substantial data requirements and seem not to be applicable over a long time periods or large data sets. Non-parametric models have hence often only been applied to a small number of observations over a small time period and to specific data. Nevertheless it may well be worth expanding the range of techniques we use in subsequent analysis.

\subsection{The Choice of Determining the CAMELS Components}

We now move from our choice of modelling technique to the choice of variables to include in the analysis. We have used the six CAMELS categories in Table 1 to classify the choices in previous work, as this format characterises not just most academic studies but also those commonly applied by supervisory authorities (Sahajwala and Van den Bergh, 2004). Despite the considerable variety of variable choice, and major divergence in effects and significance in the results, there is considerable similarity. Although no uniform way of deciding upon which indicators are to be included has been adopted, there is considerable homogeneity over which characteristics are good indicators of financial distress. However, one reason for following the layout of Table 1 is that the influencing factors may not be stable throughout time and across different markets. Unfortunately the 
problem is confounded because researchers have learned by experience at the same time that behaviour may have changed. So it is only where authors go back over a long enough dataset that they are able to show whether the change lies in the data rather than in the model.

We take the six categories in their order of appearance in CAMELS and this is repeated across the columns of Table 1 .

Capital adequacy. Not only does capital adequacy come first in the list but it is the key variable considered important in the Basel framework for ensuring healthy banks. Bank's capital serves as a cushion to absorb losses and shocks. The decline in capital relative to assets is as an indication for potential financial difficulties. Not surprisingly, nearly all previous research has included such measures (Table 1). Due to the large amount of information disclosed and the different definitions of equity there is a wide variety of potential measures. The most important distinction can be made in the weighting of risks. In the Basel framework the weighting is determined by risk-sensitivity ratios for each asset group and has to be authorised by the regulatory body. Although these risk-weighted capital ratios measures are often used, for example, in Poghosyan and Čihák (2009), the ratios face a clear drawback. They are open to manipulation and provide space for discretion to cover up the real condition of the bank ${ }^{18}$. Accordingly, other studies employ non-risk-weighted capital ratios ${ }^{19}$. The potential benefit is the avoidance of any risk assessment. We apply both risk-weighted and unweighted capital measures in estimating the potential effects to financial distress and to find the most adequate measure as part of the rationale behind the study is to determine which has worked better in the circumstances of the global financial crisis $^{20}$.

Assets and their quality. The condition and quality of individual asset categories can trigger financial problems and act as an important accelerator of bank fragility. By holding qualitatively inferior assets, the bank is more vulnerable to losses. Recognising these losses requires write downs and hence reduces the capital cushion. As a consequence of the capital loss the risk of failure increases. Due to the wide spread of banks' activities and the range of asset figures disclosed, there is a wide variety of potential indicators. Since the dominating business of commercial banks and thrifts is lending, it is reasonable to focus on this asset group. A potential measure of loan quality is to gauge the amount of provision to loan losses as in Poghosyan and Čihák (2009). As a reaction to

18 See Das and Sy (2012) and Le Leslé and Avramova (2012) for more information on the issues of risk-weighted assets.

19 This includes Avkiran and Cai (2012), Cole and Gunther (1995b), Curry et al. (2003), DeYoung (2003), Poghosyan and Čihák (2009), Männasoo and Mayes (2009) and Tatom and Houston (2011).

20 Clearly our choice of variables is constrained by the data set we use - the FDIC statistics on depository institutions (SDI) - but the choice of this dataset is itself largely driven by the very large range of information available, which permits a real choice of indicators in most cases. 
higher expected loan losses banks are forced to make higher provisions. But by inverting the argument a higher provision cannot be traced uniquely back to loan quality. Hence, another assessment might be more useful. The non-performing loan ratio, measured as non-performing loans ${ }^{21}$ to total loans, is more helpful, since the definition is more generalised, and is frequently used in the literature ${ }^{22}$.

Management competence and expertise. The ability and skill of the bank management play a crucial role in the performance and success of the institution. The higher the management competence, the lower is the vulnerability of the bank and the likelihood of making wrong decisions. Although this relationship is well-founded, the influence is hard to capture with financial data. As Table 1 shows, recent studies have implemented this component less frequently than the others. Mostly, researchers adapt and derive figures from other CAMELS categories such as earnings or asset quality indicators to approximate the management's efficiency and profitability ${ }^{23}$. Other models use accuracy measures such as efficiency in the DEA approach ${ }^{24}$. It is difficult to find an independent indicator. However, Lane, Looney and Wansley (1986) and Wheelock and Wilson (2000) incorporate measures of management efficiency that are also frequently used in practice. The FDIC also provides an efficiency ratio to assess management quality. This efficiency ratio reflects expenses as a percentage of revenue $^{25}$.

Earning ability and strength. This category reflects the sustainability of earnings and profits. Higher levels of profitability should allow banks to improve their capital and economic performance. In general, there is a negative relationship between profitability and the likelihood of distress. Insufficient ability to maintain earnings leads a bank to make losses. These losses feed back on the amount of capital and asset quality. Since banks are required to disclose key figures of profit and loss statements, there are many possible ratios to use. It is essential to adjust for risk so that the measures of returns are sensibly comparable. Recent research has applied a wide variety of earnings indicators, but the common choice is profitability or accounting measures such as cost-to-

21 The IMF (2005) defines "a loan is nonperforming when payments of interest and/or principal are past due by 90 days or more, or interest payments equal to 90 days or more have been capitalized, refinanced, or delayed by agreement, or payments are less than 90 days overdue, but there are other good reasons - such as a debtor filing for bankruptcy - to doubt that payments will be made in full."

22 See Alamet al. (2000), Henebry (1997), Halling and Hayden (2006), Tatom and Houston (2011) and Whalen (1991) for an application of the non-performing-loan ratio.

23 See for instance Halling and Hayden (2006) (earnings) and Cole and White (2012), Henebry (1997) and Thomson (1991) (asset quality indicator).

24 For the application of the DEA approach see Barr et al. (1993); Barr and Siems (1994) and Tatom and Houston (2011).

25 It is worth noting that the FDIC itself (Collier et al., 2003) does not use the M category in its SCOR financial indicator model for detecting potential problems. 
income-ratio or $\mathrm{ROA} / \mathrm{ROE}^{26}$. We follow this trend and use the net operating income to assets ratio to capture earnings strength.

Liquidity. Liquidity is essential for a bank's ability to meet and repay its short-term obligations and unexpected withdrawals of depositors and creditors. The amount of highly liquid assets is negatively correlated to the possible likelihood of distress. Recent studies have tried various ways of capturing these effects. One approach relates liquid assets such as federal funds or securities to total assets ${ }^{27}$. Other studies measure ratios between various types deposit/loans to assets ${ }^{28}$. A third well-used idea is the loan-to-deposit (LTD) ratio ${ }^{29}$. This wellknown ratio indicates the percentage of loans funded through deposits and the stability of funding. Given the emphasis on the liquidity coverage ratios and the net stable funding ratio in Basel III we apply this ratio as a liquidity measure (BCBS, 2011). Clearly it is only a good liquidity indicator for deposit-taking institutions.

Sensitivity to market risks. The concern is with the impact on banks from shifts and fluctuations in the financial market. These shifts cover not just price variations but also variations in funding. Banks are vulnerable to market distortions if they rely heavily on market refinancing or are holding highly volatile assets. As Avkiran and Cai (2012) remark, and Table 1 shows, this sixth CAMELS component has been widely neglected or ignored. This omission can be explained by difficulties in capturing this relationship with accounting and financial data. Therefore, some researchers use size of the bank as an approximation $^{30}$. However, this proxy neglects the fact that business size is not strictly accompanied by market exposure. For example, a small savings bank has a low sensitivity while a small specialized trading bank has high market sensitivity. Of course, it is important to consider the size, but it is not satisfactory to replace the sensitivity component with the size indicator. Other researchers such as Männasoo and Mayes $(2005,2009)$ or Whalen (1991) use deposits ratios to capture this effect. Others consider it more appropriate to measure the sensitivity as the bank's holding with volatile liabilities ${ }^{31}$.

\footnotetext{
26 See for instance Alam et al. (2000), Arena (2008), Avkiran and Cai (2012), Curry et al. (2003), Cole and Gunther (1995b), Cole and White (2012), Henebry (1997), Männasoo and Mayes (2005, 2009), Poghosyan and Čihák (2009), Tatom and Houston (2011) and Wheelock and Wilson (2000).

27 Cole and White (2012), Curry et al. (2003) and Wheelock and Wilson (2000) utilize such liquid assets.

28 For instance Henebry (1997), Männasoo and Mayes (2005, 2009) and Poghosyan and Čihák (2009) employ such ratios.

29 This idea is pursued by Alam et al. (2000), Tatom and Houston (2011) and Whalen (1991).

30 Abrams and Huang (1987), Avkiran and Cai (2012), Kolari et al. (2002) and Wheelock and Wilson (2000) use the size to approximate the sensitivity to market risk. This proxy also reflects the too-to-fail issue that big banks are less likely to fail (Avkiran and Cai, 2012).

31 See Evens et al. (2000) for more information on this aspect.
} 
Since the CAMELS model neglects political and economic factors along with bank strategies, some researchers implement further variables to take these influences into account ${ }^{32}$.

\subsection{Relevant Recent Experience from CAMELS-related Studies}

One of our main concerns in this article is that the global financial crisis may have revealed that the determinants of bank fragility have changed. Banking has evolved considerably in recent years, both with the move away from traditional deposit-based funding and the perceived changes in the risk environment under the 'great moderation'. Such studies as there are confirm the validity of the CAMELS approach. Curry et al. (2003) investigated US banking failures from 1988-95, applying the CAMELS approach in a logit framework. They found that considering publicly available market \& financial information only marginal improve the accuracy of the model. Tung et al. (2004) employed the CAMELS approach with the ANN technique. They were able to explain and predict financial distress very accurately over the period 1980-2000. Männasoo and Mayes (2005) employed logit technique with a five components CAMELS model and structural and macroeconomic factors in an Eastern European multi-country data set from 1996 to 2003. They showed that in addition to bank-specific factors macroeconomic factors and institutional frameworks also played an important role in determining bank distress. They also found that the determinants of failure change the closer the crisis comes, because authorities and banks try to prevent it. In their subsequent work, Männasoo and Mayes (2009), support this finding by using a refined sample in a wider time span (1995-2004) and discrete time survival analysis. Halling and Hayden (2006) employed a four components CAMELS model using the survival time analysis technique for data from 1995-2002. The work also incorporated structural factors and performs well for a sample in Austria. There is an obvious tendency, which characterises our work as well, to focus on banking crisis periods and not to consider normal periods, because this generates far more examples of failure, which aids estimation. This may bias the findings and limit their generalisability.

Poghosyan and Čihák (2009) included the early part of the GFC, using a logit model with all CAMEL categories to determinate bank failure in Europe from 1996-2008. They found consistent indicators that can help to identify banks that are vulnerable to financial distress. Jordan et al. (2010) used three CAMELS categories in combination with three institutional characteristics inside a MDA

32 For example Arena (2008), Cole and Gunther (1995b), Halling and Hayden (2006), Tatom and Houston (2011) and Tung et al. (2004) implement further variables. 
environment. They were able to predict bank distress in their three year data set (2007-10). Cole and White (2012) used logistic models and found that the traditional CAMEL approach worked adequately during the financial crisis. This finding is supported by Jin et al. (2011), who used only two CAMELS categories with other accounting, audit and financial variables in a logit model. The model is able to identify distress prior to the GFC successfully. Tatom and Houston (2011) applied the CAMEL system using the DEA approach to the GFC (2006-2010) and the Savings \& Loans crisis (S\&L) (1988-94). This model was able to predict the failures in both crisis periods accurately. Avkiran and Cai (2012) also employed a DEA model with a fully specified CAMELS model. They included financial market information such as credit ratings and were able to identify distressed banks up to two years ahead. Although the extent of the CAMEL categories used varies, the findings suggest that identification of bank distress in the GFC was possible.

\section{DATA}

This paper utilizes reports from the FDIC Statistics on Depository Institutions (SDI). These data cover only FDIC-insured institutions. The raw data set covers all insured financial institutions operating between the last quarter of 1992 and the second quarter of 2012. The data are publically available and are on a quarterly basis, providing 710,217 observations on 16,188 banks. The number of institutions is not constant over the period due to market entry and exits. As shown in Table 2, the banks have one of four principal supervisors: Federal Reserve Board (FRB), Office of the Comptroller of the Currency (OCC), Office of Thrift Supervision (OTS) and the FDIC ${ }^{33}$. The database distinguishes five categories of bank, which are labelled in Table 2. All insured depository institutions are members of the FDIC's Deposit Insurance Fund (DIF).

Since we are interested in explaining and predicting bank distress and bank failures, the dependent variable in our model is binary. If a bank fails or get into distress, the value of the variable will be 1 and otherwise 0 . The characterisation whether of a bank is assessed as distressed or failed is obtained from the public FDIC institution directory. Over the data period, 579 institutions can be identified as troubled. To be considered as troubled the financial institution must be either receiving assistance by a transaction from the FDIC or facing some kind of distress or failure in the time period. Of the 579 troubled institutions, 566 were banking failures and 13 banks got into distress and received assistance from the FDIC. Unfortunately, the FDIC does not always provide the data for the troubled

33 The Office of Thrift Supervision was dissolved and merged with the Office of the Comptroller of the Currency in July 2011. 
period, so that we are constrained to use the last available data period to model the difficulty of the bank. Therefore, there may be a divergence between the official FDIC failure date and the failure date we use. In addition, we also have to drop 26 failures from the sample that do not have sufficient available data points for the troubled period, leaving us with 553 events of bank distresses - 543 bank failures and 10 banks that have received assistance ${ }^{34}$.

Table 2: Bank \& Regulator Types

\begin{tabular}{ll|ll}
\hline \multicolumn{2}{c|}{$\begin{array}{c}\text { Banks Types } \\
\text { Abbr. }\end{array}$} & \multicolumn{1}{c}{$\begin{array}{c}\text { Abbr. } \\
\text { Description }\end{array}$} & \multicolumn{1}{c}{$\begin{array}{c}\text { Supervisor } \\
\text { Description }\end{array}$} \\
\hline $\mathrm{N}$ & $\begin{array}{l}\text { commercial bank, national (federal) charter } \\
\text { and Fed member, supervised by the OCC }\end{array}$ & FDIC & Federal Deposit Insurance Corporation \\
NM & $\begin{array}{l}\text { commercial bank, state charter and Fed non- } \\
\text { member, supervised by the FDIC }\end{array}$ & FRB & Federal Reserve Board \\
SA & $\begin{array}{l}\text { savings associations, state or federal charter, } \\
\text { supervised by the OTS }\end{array}$ & OCC & Office of the Comptroller of the Currency \\
SB & $\begin{array}{l}\text { savings banks, state charter, supervised by } \\
\text { the FDIC }\end{array}$ & OTS & Office of Thrift Supervision \\
SM & $\begin{array}{l}\text { commercial bank, state charter and Fed } \\
\text { member, supervised by the FRB }\end{array}$ & & \\
\hline
\end{tabular}

Most banks are supervised by the FDIC (Table 3) and the largest bank type is commercial banks. Most failures occurred in FDIC-supervised banks and predominantly in commercial banks with a higher proportion in these two categories than in the relative distribution of banks. Just $3.24 \%$ of the FDIC-regulated banks got into trouble. The slightly higher proportion of failures among FDIC-supervised banks is probably mainly a function of the size as failure rates among small and newer banks tend to be the largest (DeYoung, 2003).

Table 3: Allocation of Banks and Supervisor

\begin{tabular}{lrrrr|rcccc}
\hline & \multicolumn{4}{c|}{ Supervisor } & \multicolumn{5}{c}{ Banks } \\
\cline { 2 - 10 } & FDIC & FRB & OCC & OTS & N & NM & SA & SB & \multicolumn{1}{c}{ SM } \\
\hline Banks (16,188) & $51.50 \%$ & $10.78 \%$ & $25.97 \%$ & $11.75 \%$ & $23.66 \%$ & $48.44 \%$ & $12.14 \%$ & $4.64 \%$ & $11.13 \%$ \\
Failed Bank (553) & $56.96 \%$ & $10.13 \%$ & $20.98 \%$ & $11.93 \%$ & $19.89 \%$ & $54.61 \%$ & $13.02 \%$ & $2.35 \%$ & $10.13 \%$ \\
Failures & $3.24 \%$ & $2.75 \%$ & $2.37 \%$ & $2.97 \%$ & $2.54 \%$ & $3.41 \%$ & $3.24 \%$ & $1.53 \%$ & $2.75 \%$ \\
\hline
\end{tabular}

\footnotetext{
34 De novo banks have not been removed from the sample, although DeYoung (2003) proposes this as he finds that new banks have a bias and distort results. We explore this possibility in Section 5 but omission has little impact so we leave de novo banks in the main analysis.
} 
Figure 1: Number of Banks over Time

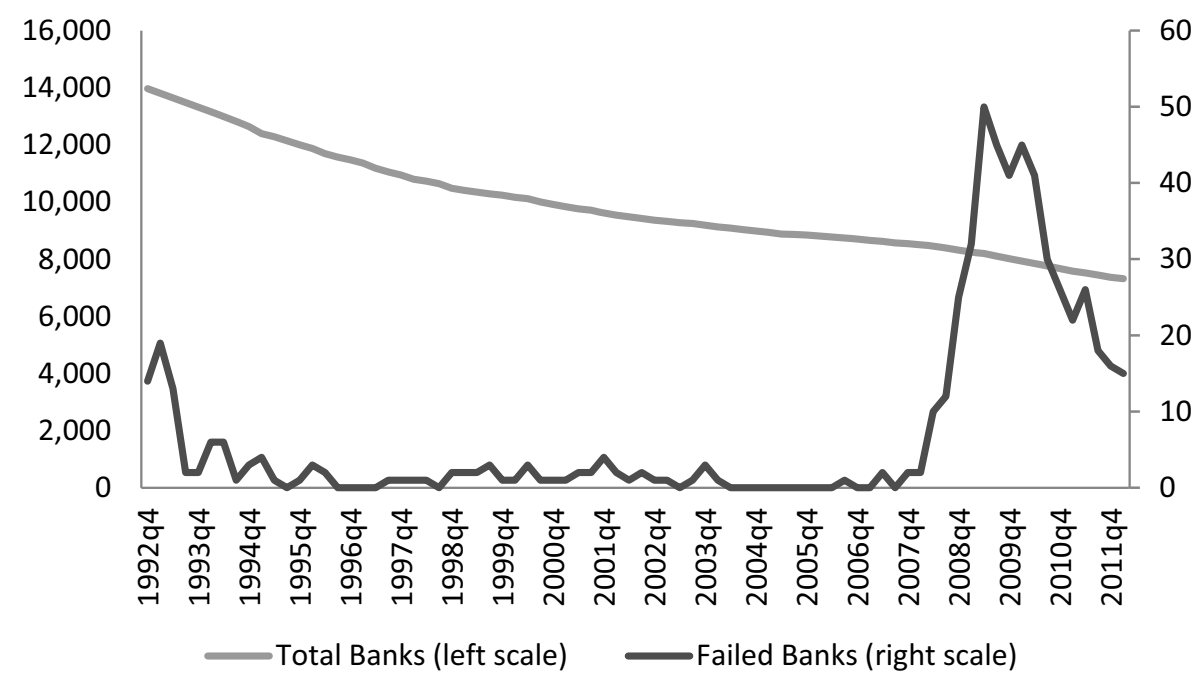

The total number of banks decreased steadily over the sample period (Figure 1). This reflects consolidation within the financial sector as well as the changing regulatory framework. There are two spikes in the number of distressed or failed banks. The first, in 1993, indicates the last consequences of the Savings \& Loan (S\&L) crisis, whereas the second, from the beginning of 2008 to the end of the sample data, reflects the global financial crisis. While bank failure or distress occurs predominantly in phases of banking or financial crisis, there are non-crisis examples.

We use a single variable to represent each of the individual C, A, M, E, L and S categories. The detailed definitions and the expected signs of their impact are given in Table 4.

We incorporate the capital adequacy in three ways: leverage ratio, risk-based capital ratio, and gross revenue ratio ${ }^{35}$. For the risk-based capital ratio we use the total capital ratio which is adopted in Basel II/III. The non-risk-weighted leverage ratio is total equity minus estimated losses to assets. The gross revenue ratio is tier 1 capital to total interest and noninterest income. We incorporate only one indicator at a time as they are substantially substitutes empirically. For all capital indicators we assume a negative relationship to banking failure; the lower the capital adequacy, the more likely is a failure. To estimate asset quality we use the ratio of nonperforming loans to total. We anticipate a positive relationship with

35 The definition of the variables is based on Estrella, Park and Peristiani (2000). We incorporate the total risk-based capital, since other potential measures such as Tier 1 or Tier 2 capital ratio are not available in the data for the whole sample. 
Table 4: Variable Definitions

\begin{tabular}{l|l|c|c}
\hline Variables & \multicolumn{1}{|c|}{ Definition } & Influence & Source \\
\hline Capital (LEV) & $\begin{array}{l}\text { Leverage Ratio: } \\
\text { Total Equity minus Estimated Losses to Assets }\end{array}$ & FDIC \\
\hline Capital (RBC) & $\begin{array}{l}\text { Risk-Weighted Capital Ratio: } \\
\text { Total Risk-Based Capital Ratio }\end{array}$ & - & FDIC \\
\hline Capital (GRR) & $\begin{array}{l}\text { Gross Revenue Ratio: } \\
\text { Tier 1 Capital to Total Interest and Noninterest Income }\end{array}$ & - & FDIC \\
\hline Assets & $\begin{array}{l}\text { Nonperforming Loans } \\
\text { (Noncurrent Assets plus Other Real Estate Owned to Assets) }\end{array}$ & + & FDIC \\
\hline Management & Efficiency Ratio & + & FDIC \\
\hline Earnings & Net Operating Income to Assets & - & FDIC \\
\hline Liquidity & Net Loans and Leases to Deposits & + & FDIC \\
\hline Sensitivity & Volatile Liabilities to Assets & + & FDIC \\
\hline GDP & $\begin{array}{l}\text { Seasonally Adjusted Percentage Change from Preceding Period } \\
\text { in Real Gross Domestic Product }\end{array}$ & - & BEA \\
\hline
\end{tabular}

banking failure, the larger the proportion of non-performing loans, the more likely is a failure. For management competence and expertise of banks we use the efficiency ratio provided by the FDIC. It measures the proportion of net operating revenues that are absorbed by overhead expenses and a lower value indicates greater efficiency. Therefore, we assume a positive relationship; the higher the ratio, the more likely is a failure.

We follow the trend of using the net operating income to assets ratio to capture the earning ability and strength of the banks and assume a negative relationship with banking. The lower the earnings, the more likely a failure is. For liquidity we use the loan-to-deposit ratio (LTD) to capture this effect as no direct liquidity measures are available. A high LTD ratio may indicate the lack of liquidity and possible repayment problems for sudden unforeseen obligations. We expect a positive sign for the liquidity indicator. It is difficult to find an adequate indicator for the sensitivity to market risks, since different banking businesses have varying degrees of market engagement. We measure the sensitivity as the bank's dependence on volatile liabilities; sometimes this ratio is also used to measure liquidity (Curry, Fissel and Elmer, 2003). The ratio is calculated as total volatile liabilities divided by total assets. We expect a positive sign for the sensitivity indicator.

All explanatory variables have been winsorized ${ }^{36}$ at the $1 \%$ level separately for crisis and non-crisis events to remove data errors and anomalies. The

36 For more information on winsorizing see for instance Barnett and Lewis (1994) 
observations of banking failures and distress events have been excluded from this process, since we assume that they are tail events and hence would be removed from the sample.

Banks' characteristics alone may be insufficient to determine failure as the phase of the economic cycle may have an impact. Failure is more likely in unfavourable conditions ${ }^{37}$. Therefore, we include real gross domestic product (GDP) to capture this, as in Männasoo and Mayes (2005, 2009). It is measured as the seasonally adjusted percentage change from preceding period in real gross domestic product based on the data from the Bureau of Economic Analysis (BEA). The expected sign of GDP is hence negative.

The mean values of variables for healthy banks and troubled banks are clearly different (Table 5). Since there are so few troubled banks the mean values of the total sample are very close to the ones in the healthy bank subsample. Not surprisingly, troubled banks have a lower mean in the categories of capital, management, earnings and GDP in comparison to the healthy banks, but their mean values in the categories assets, liquidity and sensitivity are higher, reflecting our expectation. The means for distressed banks are clearly higher, but have very large standard deviation. This may indicate that while the indicator is suitable for some distress events it may be less practicable for others. To lesser extent this might be true for the gross revenue ratio and liquidity indicator and may indicate difficulties in measuring these effects.

Table 5: Descriptive Statistics

\begin{tabular}{l|c|c|c|c|c|c}
\hline \multirow{2}{*}{ Variable Name } & \multicolumn{2}{|c|}{ Total Sample (N=710217) } & \multicolumn{2}{l}{ Healthy Banks (N=709664) } & \multicolumn{2}{c}{ Distressed Banks (N=553) } \\
\cline { 2 - 7 } & Mean & Std. Dev. & Mean & Std. Dev. & Mean & Std. Dev. \\
\hline Capital (LEV) & 0.0940 & 0.0368 & 0.0940 & 0.0366 & -0.0129 & 0.0483 \\
\hline Capital (RBC) & 0.1004 & 0.0356 & 0.1004 & 0.0356 & 0.0161 & 0.0356 \\
\hline Capital (GRR) & 3.1759 & 2.4788 & 3.1778 & 2.4780 & 0.7339 & 2.3386 \\
\hline Assets & 0.0119 & 0.0170 & 0.0118 & 0.0163 & 0.1555 & 0.0944 \\
\hline Management & 0.6704 & 0.3677 & 0.6691 & 0.1916 & 2.3771 & 11.1306 \\
\hline Earnings & 0.0094 & 0.0095 & 0.0094 & 0.0091 & -0.0622 & 0.0649 \\
\hline Liquidity & 0.8895 & 0.3713 & 0.8892 & 0.3429 & 1.2536 & 5.1004 \\
\hline Sensitivity & 0.1458 & 0.1014 & 0.1458 & 0.1014 & 0.1671 & 0.1436 \\
\hline GDP & 0.0269 & 0.0254 & 0.0269 & 0.0254 & 0.0118 & 0.0322 \\
\hline
\end{tabular}

\footnotetext{
37 In this paper we do not include any market information indicator such as bond spreads, CDS or VIX, as our sample mainly includes non-listed regional banks, which tend to re-finance themselves outside financial markets.
} 
Table 6: Correlation Matrix

\begin{tabular}{|c|c|c|c|c|c|c|c|c|c|}
\hline Variable Name & 苞疍 & 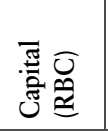 & 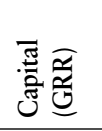 & $\begin{array}{l}\text { 岕 } \\
\text { 足 }\end{array}$ & 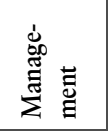 & $\begin{array}{l}\text { 量 } \\
\text { 量 } \\
\text { 氙 }\end{array}$ & 穿 & 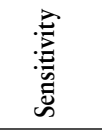 & जิ \\
\hline Capital (LEV) & 1.0000 & & & & & & & & \\
\hline Capital (RBC) & 0.9304 & 1.0000 & & & & & & & \\
\hline Capital (GRR) & 0.4840 & 0.4288 & 1.0000 & & & & & & \\
\hline Assets & -0.1155 & -0.0626 & 0.0102 & 1.0000 & & & & & \\
\hline Management & -0.1151 & -0.1049 & 0.0330 & 0.3406 & 1.0000 & & & & \\
\hline Earnings & 0.1343 & 0.1412 & -0.0581 & -0.4383 & -0.7650 & 1.0000 & & & \\
\hline Liquidity & -0.0128 & 0.0069 & -0.0669 & 0.0919 & -0.0157 & -0.0370 & 1.0000 & & \\
\hline Sensitivity & -0.0911 & -0.0904 & -0.0858 & -0.0288 & 0.0050 & -0.0583 & 0.6630 & 1.0000 & \\
\hline GDP & -0.0361 & -0.0231 & -0.1936 & -0.1162 & -0.1043 & 0.1165 & -0.1277 & -0.1014 & 1.0000 \\
\hline
\end{tabular}

The CAMELS indicators are little correlated with each other (Table 6), so that this should limit any problems from multi-collinearity in estimation. There are two exceptions. The earnings variable is considerably negatively correlated with the indicators of assets and management and the liquidity variable is substantially positively correlated with the sensitivity indicator. The former correlation suggests that inferior asset quality is accompanied by weaker earnings. These earnings also have a substantial influence to the efficiency ratio. The latter correlation indicates that the sensitivity to markets indictor is interrelated with liquidity, which is the case by definition ${ }^{38}$. In addition to the correlation matrix, we have also checked for suspicious variance inflation factors and find no abnormality. All factors are in the interval between 1 and 2 . Therefore, the data do not seem to contain any serious correlation issues and we can use our estimation techniques. The capital adequacy indicators are substitutes and not used simultaneously. Nonetheless, the correlation suggests that the explanatory powers of the leverage and risk-based capital ratio might be close.

\section{RESULTS}

It is worth noting some prima facie indicators that are clear from the data (Figure 2). Both the banks which ultimately failed and those that did not tended to run their capital adequacy down in the period up to the global financial crisis. While on average, those who ultimately failed tended to have around 5\% less capital even in the best years, the gap widened from 1997. This illustrates that the fragility was being built up over a longer period rather than simply that losses

\footnotetext{
38 In fact, some researcher like Curry, Fissel, and Elmer (2003) use this ratio to capture liquidity aspects.
} 
were incurred in the global financial crisis to banks that had not otherwise shown signs of weakness. Since we aim to find robust indicators for detecting bank failures, we apply two different estimation techniques to satisfy this demand. Multivariate logit estimation is applied in a panel data environment as well as time survival analysis in the time dimension and hence on the time to default. We start by using the logit approach, conditioned on balance sheet and economic indicators for each bank to determine the best capital adequacy indicator from the model. The regression model has the following specification:

$$
\begin{aligned}
D_{i}= & \left\{\begin{array}{l}
=1 \text { if bank } i \text { is distressed or fails } \\
=0 \text { otherwise }
\end{array}\right. \\
D_{i t}= & \text { Cons }+\beta_{C} X_{C, i t}+\beta_{A} X_{A, i t}+\beta_{M} X_{M, i t}+\beta_{E} X_{E, i t} \\
& +\beta_{L} X_{L, i t}+\beta_{S} X_{S, i t}+\beta_{G D P} X_{G D P, t}
\end{aligned}
$$

where the vector of explanatory variables $X$ contains: capital adequacy $C$, asset quality $A$, management expertise $M$, earnings strength $E$, liquidity $L$ and sensitivity to market risks $S$ as well as $G D P$. In addition, we also incorporate a constant in our model to take account of other influences that are not reflected by our explanatory variables and we apply a random effects panel approach.

Figure 2: Ratio of Risk-weighted Assets to Total Assets

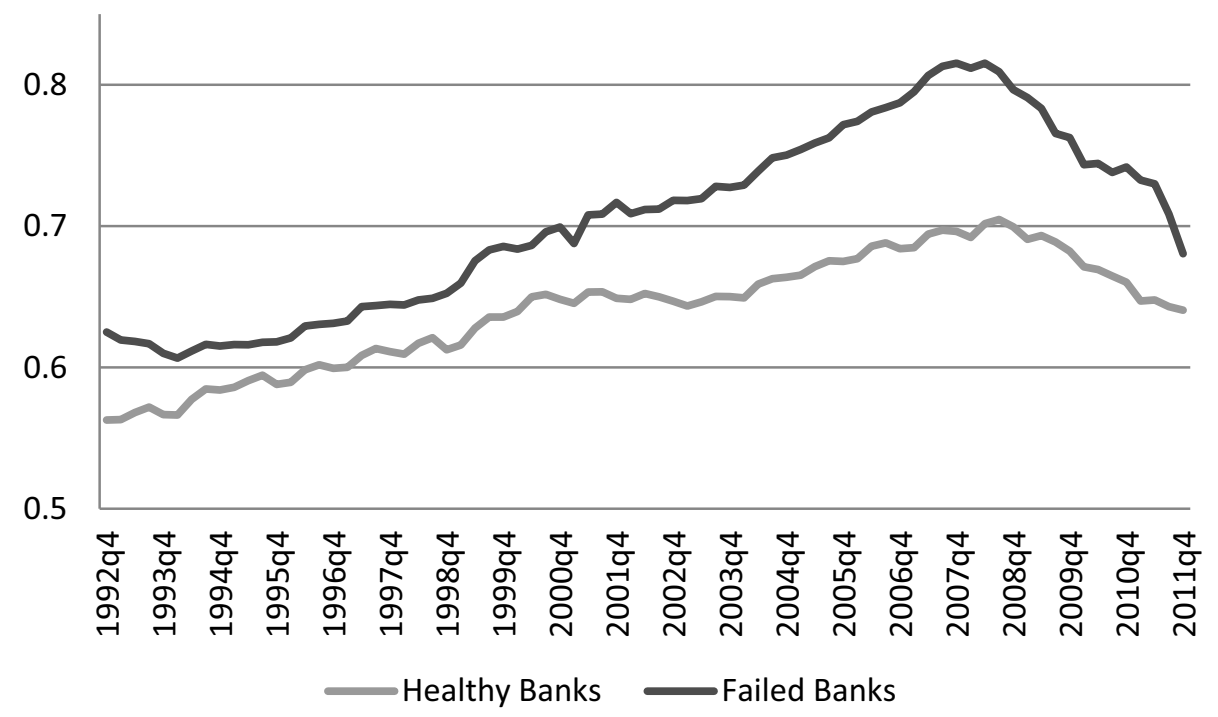


Table 7: Logit Models with Different Capital Adequacy Measures

\begin{tabular}{|c|c|c|c|}
\hline Indicators & Model (1) & Model (2) & Model (3) \\
\hline Capital (LEV) & $\begin{array}{l}-127.7^{* * * *} \\
(-22.96)\end{array}$ & & \\
\hline Capital (RBC) & & $\begin{array}{l}-148.4^{* * * *} \\
(-23.55)\end{array}$ & \\
\hline Capital (GRR) & & & $\begin{array}{l}-0.830^{* * *} \\
(-11.24)\end{array}$ \\
\hline Assets & $\begin{array}{l}22.89^{* * * *} \\
(9.40)\end{array}$ & $\begin{array}{l}28.52^{* * * *} \\
(11.84)\end{array}$ & $\begin{array}{l}51.71^{* * * *} \\
(25.56)\end{array}$ \\
\hline Management & $\begin{array}{l}0.104^{* * *} \\
(1.98)\end{array}$ & $\begin{array}{l}0.0543 \\
(0.53)\end{array}$ & $\begin{array}{l}0.141^{\text {*** * }} \\
(3.57)\end{array}$ \\
\hline Earnings & $\begin{array}{l}-13.27^{* * * *} \\
(-3.51)\end{array}$ & $\begin{array}{l}-14.43^{* * *} \\
(-3.45)\end{array}$ & $\begin{array}{l}-47.36^{* * * *} \\
(-15.96)\end{array}$ \\
\hline Liquidity & $\begin{array}{l}0.682^{* * *} \\
(4.14)\end{array}$ & $\begin{array}{l}1.034^{* * * *} \\
(3.56)\end{array}$ & $\begin{array}{l}0.593^{* * * *} \\
(2.73)\end{array}$ \\
\hline Sensitivity & $\begin{array}{l}1.211^{*} \\
(1.80)\end{array}$ & $\begin{array}{c}0.186 \\
(0.22)\end{array}$ & $\begin{array}{l}-0.400 \\
(-0.66)\end{array}$ \\
\hline GDP & $\begin{array}{l}-12.40^{* * *} \\
(-5.53)\end{array}$ & $\begin{array}{l}-13.05^{* * * *} \\
(-5.54)\end{array}$ & $\begin{array}{l}-7.312^{* * *} \\
(-4.19)\end{array}$ \\
\hline Constant & $\begin{array}{l}-2.739 * * * \\
(-7.41)\end{array}$ & $\begin{array}{l}-0.253 \\
(-0.52) \\
\end{array}$ & $\begin{array}{l}-9.446^{* * * *} \\
(-32.65)\end{array}$ \\
\hline Total Observations & 710217 & 710217 & 710217 \\
\hline \# of Bank Failures & 553 & 553 & 553 \\
\hline Log Likelihood & -792.8 & -784.3 & -1251.8 \\
\hline $\mathrm{AIC}$ & 1603.6 & 1586.5 & 2521.7 \\
\hline $\mathrm{BIC}$ & 1706.9 & 1689.8 & 2625.0 \\
\hline
\end{tabular}

$t$ statistics in parentheses

$* p<0.1, * * p<0.05, * * p<0.01$

The three columns of Table 7 contrast the results from using the three different capital adequacy measures: (1) the leverage ratio (LEV), (2) the risk-weighted capital ratio (RBC) and (3) the gross revenue ratio (GRR), respectively. The indicators in the first and second specifications have all the expected signs (Table 7) but there are some drawbacks. Model (2) and (3) fail to find a significant influence from the sensitivity variable on the distress of banks. The management variable has no significant influence to the distress of banks in the specification (2). This model also suggests that the inclusion of the constant may be irrelevant. For models (1) and (2) capital adequacy is the major driver in explaining of bank distress, but this is less evident in model (3) but still a highly significant explanation. In all models, asset quality and earning ability are able to explain a considerable amount of the variation. Further, GDP has the expected clear effect. 
In an economic downturn the likelihood of a financial institution getting into distress is much higher than in good times. A lack of liquidity raises the vulnerability of banks in all models. Indeed, it is a lack of liquidity not capital that leads to the immediate closure of a bank. Interestingly, the liquidity variable has very limited explanatory power. In addition to the insignificant parameter of management and sensitivity, model (3) also has high standard errors for many coefficients, which may indicate that this model is poorly specified. This is confirmed by the log likelihood ratio and information criteria. In total, there is little to choose between models (1) and (2).

Turning to the time survival analysis, we use Cox (1972) proportional hazard estimation. The Cox proportional hazard model incorporates the time dimension in the prediction and offers a further approach to testing for the best predictions. We use the same three possible specifications in a time survival analysis and employ the same explanatory variables as in the logit models. Again, the leverage ratio, the risk-weighted capital ratio and the gross revenue ratio form three competing specifications labelled (1), (2) and (3).

It is immediately clear from Table 8 that these models do not explain behaviour in as well determined a manner as the logit model. Except for GDP and sensitivity, the coefficients have the expected signs. Nevertheless, the coefficients for management, sensitivity and the GDP indicator are not or only barely significant. Unlike the logit model, all three models show a clear and similar influence from capital adequacy, assets and liquidity. As before capital adequacy and then the amount of non-performing loans (asset quality) showed the most important influence on bank distress. Although earnings are generally less important in the time survival, they have a substantial influence on the likelihood of insolvency. Again there is little to choose between models (1) and (2), although the individual coefficients are somewhat better determined.

Taken together, we get similar results to other authors. Capital adequacy, assets (non-performing loans), liquidity and earnings have a clearly distinguishable influence on bank distress. Management and sensitivity seem to be less important. Less clear, rather surprisingly is the general influence of economic conditions. There is little to distinguish performance of the leverage ratio from the commonly used risk-based capital ratio as a capital adequacy indicator. However, what is notable is that, in contrast to Estrella, Park, and Peristiani (2000), the GRR does not seem to be so useful. 
Table 8: Time Surviving Analyses with Different Capital Adequacy Measures

\begin{tabular}{l|c|c|c}
\hline & Model (1) & Model (2) & Model (3) \\
\hline Capital (LEV) & $-124.3^{* * *}$ & & \\
\hline Capital (RBC) & & & \\
& & $-147.4^{* * *}$ & $(-23.18)$ \\
\hline Capital (GRR) & & & $-1.052^{* * *}$ \\
& & & $(-17.04)$ \\
\hline Asset & $24.78^{* * *}$ & $31.49^{* * *}$ & $50.54^{* * *}$ \\
& $(9.49)$ & $(11.40)$ & $(22.92)$ \\
\hline Management & $0.114^{* *}$ & 0.0727 & $0.127^{* * *}$ \\
\hline Earnings & $(2.23)$ & $(0.63)$ & $-41.67^{* * *}$ \\
& $-8.553^{* *}$ & $-9.087^{* *}$ & $(-13.38)$ \\
\hline Liquidity & $(-2.25)$ & $(-2.07)$ & 0.391 \\
& $0.708^{* * *}$ & $1.119^{* * * *}$ & $(1.70)$ \\
\hline Sensitivity & $(4.89)$ & $(3.41)$ & -0.0297 \\
& -0.410 & -1.669 & 1.286 \\
\hline GDP & $(-0.51)$ & $(-1.53)$ & $(0.03)$ \\
\hline Total Observations & 44.81 & $45.14^{*}$ & 710102 \\
\hline \# of Bank Failures & $(1.42)$ & $(1.92)$ & 553 \\
\hline Log Likelihood & 710102 & 710102 & -1055.5 \\
\hline AIC & 553 & 553 & 2124.9 \\
\hline BIC & -680.9 & -667.9 & 2205.2 \\
\hline$t$ statistics in par & 1349.8 & 1430.1 & \\
\hline
\end{tabular}

$t$ statistics in parentheses

$* p<0.05, * * p<0.01, * * p<0.001$

\section{Prediction AcCuracy and Forecasting Ability}

Previous literature warns that bank distress and failure are difficult to predict (Worrell, 2004), so we assess the in-sample and out-of-sample predictive power for both estimation techniques. For the logit model we use the linear prediction technique with a cut-off point at $50 \%$. All predictions with a value over $50 \%$ are considered as indicating failures. For the time survival analysis we employ Harrell's concordance coefficient to assess the predictive quality of the different models ${ }^{39}$. The in-sample prediction accuracy is shown in Table 9.

39 Harrell's 'C' concordance coefficient was proposed and developed by Harrell, Califf, Pryor, Lee and Rosati (1982), and Harrell, Lee and Mark (1996). 
Table 9: Prediction Accuracy

\begin{tabular}{lcc}
\hline \multirow{2}{*}{ Capital Adequacy } & \multicolumn{2}{c}{ Bank Distress } \\
\cline { 2 - 3 } & correctly detected & falsely detected \\
\hline Leverage Ratio & Logit Model & - \\
Risk-Based Capital & $80.11 \%$ & - \\
Gross Revenue Ratio & $79.93 \%$ & - \\
\hline & $58.63 \%$ & - \\
Leverage Ratio & Hazard Model & - \\
Risk-Based Capital & $97.10 \%$ & - \\
Gross Revenue Ratio & $97.12 \%$ & \\
\hline
\end{tabular}

Before interpreting the results it is worth noting the accuracy of the estimation techniques cannot be directly compared, because the techniques are based on different assumptions. Nonetheless, some inferences can be drawn. First of all, none of the models falsely detect banking failures, so there are no type II errors. Again the leverage ratio and risk-based capital measures show similar performance. With the logit technique we can classify $80 \%$ of all distress and failure events of financial institutions correctly and with the time survival model about $97 \%{ }^{40}$. In contrast, the forecasting ability of the gross revenue ratio logit model is clearly worse.

However, these findings relate to in-sample predictions where accuracy is expected to be good. To mimic real life, where one has no knowledge of the events to come we re-estimate the models from 1990s only up to the beginning of the GFC and make predictions about its failures during the GFC to give out-ofsample forecasts ${ }^{41}$. We only show results for the leverage ratio as these were the more robust. This sub-sample (Q4/1992-Q2/2007) covers 113 in sample failure events of which can predict $74(65 \%)$. We use these estimates to predict the 443 failures during the GFC. We are able to predict $83 \%$ (368) of these failures. This suggests that the causes of failures in the GFC are not different from previous failures and that despite any differences in the individual coefficients from using the shorter data period, their predictive ability remains good.

We take this approach further by seeing how progressive out-of-sample prediction ability would have been if each year the model was re-estimated to take all the available data into account ${ }^{42}$. We are in effect applying a rolling regression,

\footnotetext{
40 We have also checked for different cut-off points. The results are in line with our findings. However, for example for the logit model, the accuracy declines at the $75 \%$ and $90 \%$ cut-off points to $72 \%$ and $65 \%$, respectively.

41 The regression results with the logit model are similar to those with the full sample; only the sensitivity and GDP coefficients are insignificant.

42 Clearly the model can be re-estimated each quarter as we do below but we only illustrate annual steps here.
} 
although the starting date remains fixed. First, we estimate from 1992 to 2005 and then predict all remaining failures. We then roll the end date of the panel forward a year at a time to 2010 and predict the remaining failures on each. The predictive accuracy of different windows is shown in Table 10 . The quality of the in-sample predictions remains stable, improving somewhat when 2010 is added, suggesting that the explanatory power is not only driven by the failures in the global financial crisis. Out-of-sample prediction ability remains good throughout, not surprisingly rising as the prediction period shortens.

Table 10: Prediction Accuracy of Various Time Windows

\begin{tabular}{l|cc|cc}
\hline \multirow{2}{*}{$\begin{array}{l}\text { Last Quarter of } \\
\text { Estimation }\end{array}$} & \multicolumn{2}{|c|}{ In-Sample } & \multicolumn{2}{c}{ Out-of Sample } \\
\cline { 2 - 5 } & Predicted Failure & \# Failures & Predicted Failure & \# Failures \\
\hline Total Sample & $80.11 \%$ & 553 & & 441 \\
2005 Q4 & $67.86 \%$ & 112 & $82.09 \%$ & 441 \\
2006 Q4 & $67.86 \%$ & 112 & $82.09 \%$ & 437 \\
2007 Q4 & $65.52 \%$ & 116 & $83.35 \%$ & 388 \\
2008 Q4 & $61.82 \%$ & 165 & $85.31 \%$ & 229 \\
2009 Q4 & $70.67 \%$ & 324 & $89.96 \%$ & 94 \\
2010 Q4 & $76.47 \%$ & 459 & $95.74 \%$ & \\
\hline
\end{tabular}

Additionally, we investigate the development and the relation of the regression coefficients in the GFC. Figure 3 shows the development of the estimates from 24 rolling regressions from 2005Q1 to 2010Q4 ${ }^{43}$. Not surprisingly because we quickly add far more failures than we had in the pre-GFC data set, the coefficients start changing, quite substantially for some of the poorly determined estimates. From 2008 to 2009 the capital indicator coefficient falls by nearly a quarter of its value before rising again to within $10 \%$ of its pre-GFC value. This pattern is accompanied by an increasing asset quality and declining earnings coefficients as the GFC takes hold. However, in the latter case the change is more than reversed by the end of the period. These paths as well as the spike in the liquidity indicator coefficient (liquidity squeeze) reflect characteristics of the global financial crisis. But, capital, earnings and liquidity remain the main drivers. Although the ranking of their relative importance does not vary, their magnitude does, reflecting the features of the newly incorporated failures.

In common with many other EWS models, but unlike Männasoo and Mayes $(2005,2009)$, we have up to this point been using models that 'explain' failures in terms of the CAMELS indicators. We turn to the forecasting ability of the logit

43 The coefficients for management, sensitivity, and GDP are sometimes insignificant. 
Figure 3: Stability of Coefficients

Capital

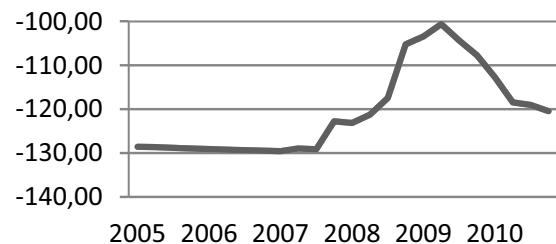

Management

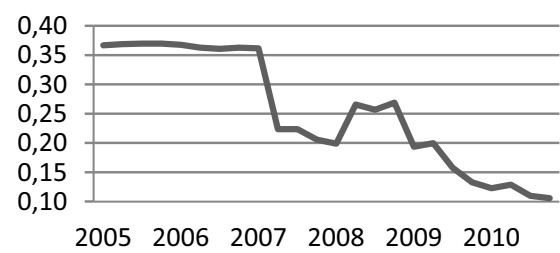

Liquidity

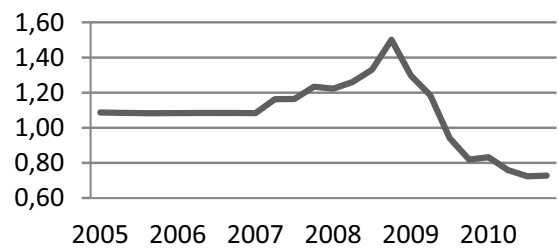

Asset

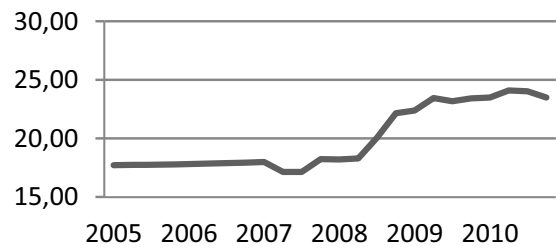

Earnings

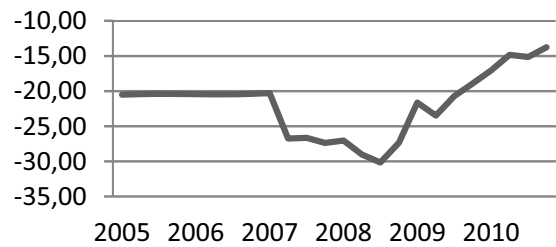

Sensitivity

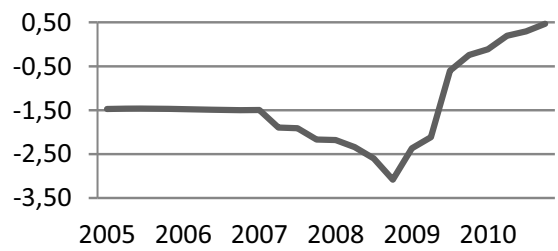

model and forecast the dependent variable up to four quarters ahead $\left(t_{+1} \rightarrow t_{+4}\right)$ only using the information at $t_{0}$. We forecast failures for all three logit specifications (Table 11 ) with two different thresholds $(25 \%$ and $50 \%)$ for the probability of a failure. The leverage ratio and risk-weighted specifications have very similar success rates in forecasting distress over all horizons and probabilities. Both models can explain nearly $80 \%$ of the failures one and two periods ahead. The GRR model lags behind with $59 \%$ and detects one 'false' failure. That confirms the findings of Section 3 that the GRR is not the best specified model. The forecasting ability three quarters and four quarters ahead is much worse in every instance. At three and four quarters ahead it is only possible to forecast about one failure in seven with the $50 \%$ threshold. At the same time, the number of forecasts of failures that did not happen also rises to around $10 \%$ of the total number of failures. The marked decline is expected, since the indicators are based on balance sheets figures. The further ahead the forecasted period, the lower the prediction quality is and the higher the forecasting errors are. At the $25 \%$ threshold for the first two periods, the forecasting ability is a 
little better than with the $50 \%$ thresholds. The three and four quarter ahead forecasts are not surprisingly a little better at one in five failures, but this is at the expense of falsely identified failures rising to the same level.

Figure 4: ROC curves

(a) Leverage ratio

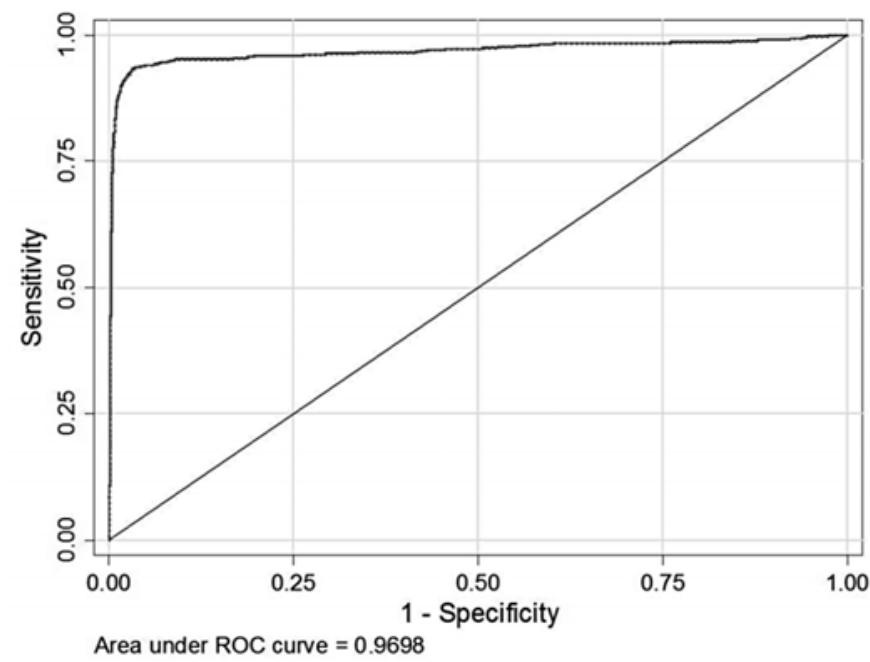

(b) Risk-weighted capital ratio

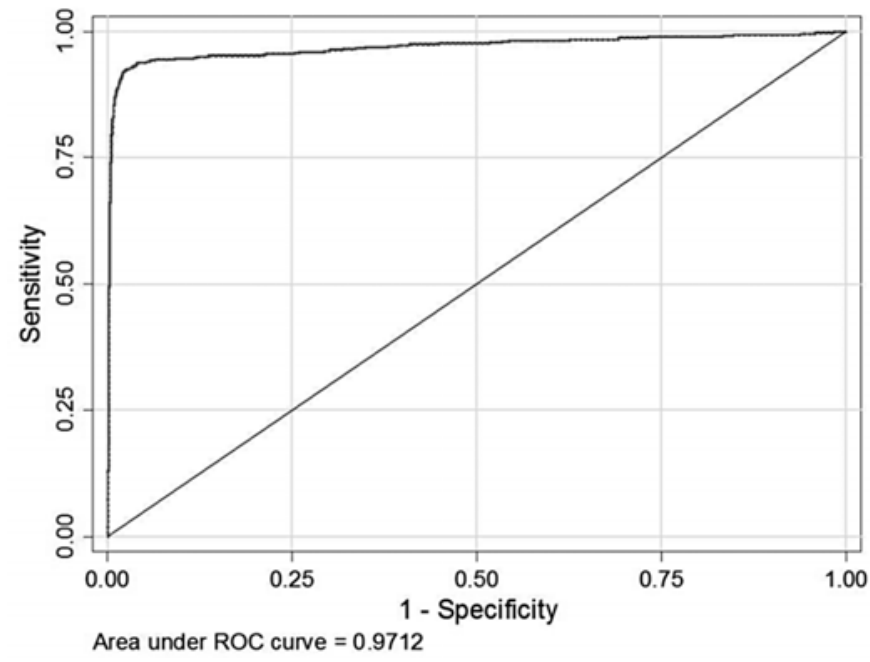

The area under the ROC (Receiver Operating Characteristic) curve (Figure 4) at 0.971 for the model using risk-weighted capital and 0.970 when using the 


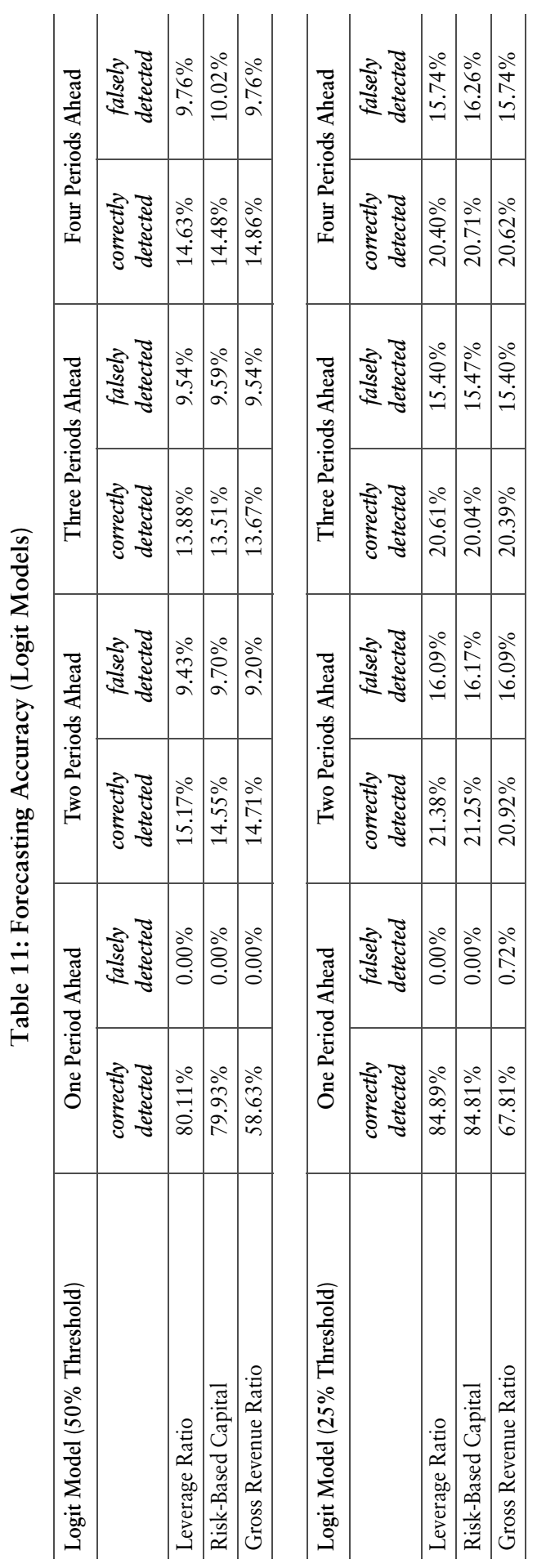


Figure 5: Distress Revealed in Individual Banks

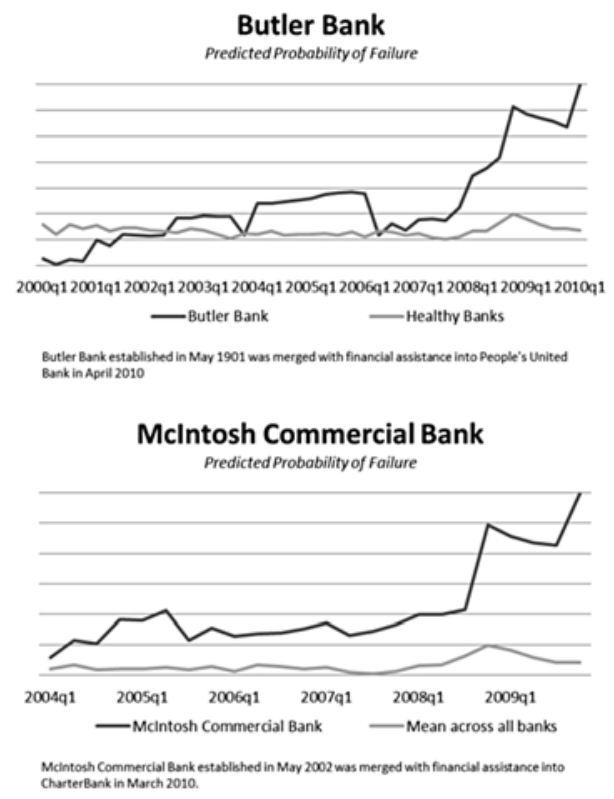

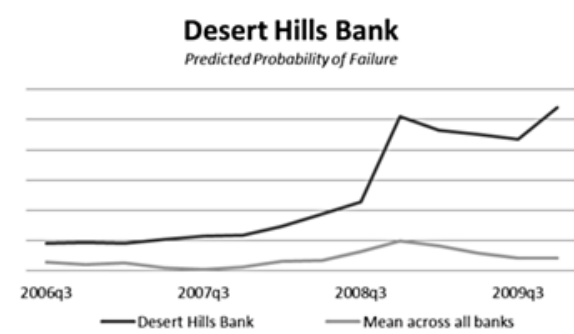

Desert Hills Bankestablished in May 2000 was merged with financial assistance into New York Community Bank in March 2010 .

Peoples Bank and Trust Predicted Probability of failure

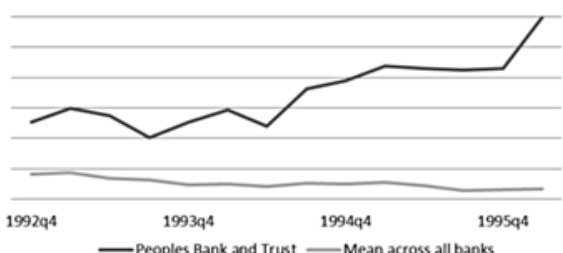
May 1962 was merged with finuncial assistance into Boatmen's Fist National Rank of Amarillo in Mar 1996

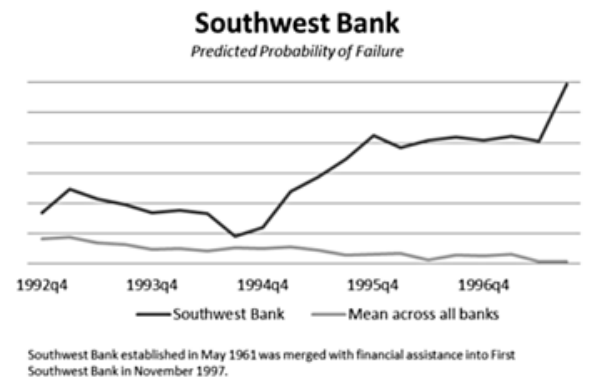

leverage ratio suggests that the model works very well in classifying distress ${ }^{44}$. However, it remains that banks normally seem to sink into difficulty quite quickly. In Figure 5 we show five examples of individual banks using the leverage ratio model picked at random from our dataset. In each case difficulties emerge very rapidly and there is no period where a bank shows difficulty but not impending disaster. The switch from behaving normally to being in serious danger appears to occur within a matter of months. There is no interim period where a recovery might be possible. In these cases the FDIC would have moved

\footnotetext{
44 Admittedly, the high ROC values seem to be mainly driven by the overwhelming majority of non-distress events in comparison to distress events. Nevertheless, ROC values remain considerable high when we vary the sample size.
} 
quickly towards a smooth and low cost resolution. While a recovery strategy is normally sought, in practice it is not usually possible to attain it.

These results confirm what many supervisors find: that failures are very difficult to forecast more than six months ahead, but they are much easier to detect within that horizon. Hence a well-designed EWS (on the basis of the US data) could provide the necessary warning time to put all the measures in place needed for an orderly failure. It is also clear that the simple leverage ratio performs just as well as the more sophisticated risk-weighted measures, so there is no predictive gain from the complexity.

\section{TEST OF ROBUSTNESS}

It is possible that we have omitted other characteristics of banks that contribute to their failure or avoidance of failure. Such omissions could both reduce potential predictive performance and bias the included coefficient estimates. We therefore test for the presence of six further possible explanatory variables, both individually and jointly. These are as follows:

- $\quad$ model (2) incorporates the size of the institution;

- $\quad$ model (3) includes the age of the business;

- $\quad$ model (4) considers the effects of ownership type;

- model (5) takes into account whether the institution is part of a holding company;

- $\quad$ model (6) tackles the wide-spread impression that the GFC was different;

- $\quad$ model (7) considers whether failure rates are affected by who the supervisor is; and finally

- model (8) contains a parsimonious specification of all of the above possibilities.

The results are shown in Table 12 .

We use the leverage ratio logit model, model (1), as the base for these tests. In the re-estimation, the coefficients of the explanatory variables (CAMELS \& GDP) vary somewhat but have the expected signs and are significant.

As a first step, we consider bank size, measured as the log of assets as a possible influence ${ }^{45}$. Smaller banks are more likely to fail, because bigger institutions tend to be more diversified and in some cases more likely to be treated favourably because of the adverse consequences of their failure. We hence expect a negative sign. However, our sample does not confirm this hypothesis, the sign is positive and the variable is insignificant. There is a second reason for expecting that size

45 The size variable has also been winsorized to be consistent with the CAMELS indicators. 
Table 12: Robustness Checks

\begin{tabular}{|c|c|c|c|c|c|c|c|c|}
\hline & Model (1) & Model (2) & Model (3) & Model (4) & Model (5) & Model (6) & Model (7) & Model (8) \\
\hline Capital (LEV) & $\begin{array}{l}-127.7^{* * *} \\
(-22.96)\end{array}$ & $\begin{array}{l}-127.5^{* * *} \\
(-22.96)\end{array}$ & $\begin{array}{l}-127.7^{* * *} \\
(-22.87)\end{array}$ & $\begin{array}{l}-127.6^{* * *} \\
(-22.86)\end{array}$ & $\begin{array}{l}-127.7^{* * *} \\
(-22.94)\end{array}$ & $\begin{array}{l}-127.7^{* * *} \\
(-22.97)\end{array}$ & $\begin{array}{l}-127.6^{* * * *} \\
(-22.91)\end{array}$ & $\begin{array}{l}-127.2^{* * *} \\
(-22.88)\end{array}$ \\
\hline Assets & $\begin{array}{l}22.89^{* * *} \\
(9.40)\end{array}$ & $\begin{array}{l}22.73 * * * \\
(9.32)\end{array}$ & $\begin{array}{l}23.55^{* * *} \\
(9.51)\end{array}$ & $\begin{array}{l}23.16^{* * *} \\
(9.43)\end{array}$ & $\begin{array}{l}22.90^{* * *} \\
(9.40)\end{array}$ & $\begin{array}{l}22.56^{* * *} \\
(8.98)\end{array}$ & $\begin{array}{l}23.59^{* * *} \\
(9.52)\end{array}$ & $\begin{array}{l}24.11^{* * *} \\
(9.64)\end{array}$ \\
\hline Management & $\begin{array}{l}0.104^{* *} \\
(1.98)\end{array}$ & $\begin{array}{l}0.105^{* *} \\
(2.06)\end{array}$ & $\begin{array}{l}0.107^{* * *} \\
(2.07)\end{array}$ & $\begin{array}{l}0.104^{*} \\
(1.93)\end{array}$ & $\begin{array}{l}0.104^{* * *} \\
(1.97)\end{array}$ & $\begin{array}{l}0.102^{*} \\
(1.93)\end{array}$ & $\begin{array}{l}0.105^{* *} \\
(2.04)\end{array}$ & $\begin{array}{l}0.103^{*} \\
(1.89)\end{array}$ \\
\hline Earnings & $\begin{array}{l}-13.27^{* * *} \\
(-3.51)\end{array}$ & $\begin{array}{l}-13.98^{* * *} \\
(-3.69)\end{array}$ & $\begin{array}{l}-13.72^{* * *} \\
(-3.61)\end{array}$ & $\begin{array}{l}-13.66^{* * *} \\
(-3.63)\end{array}$ & $\begin{array}{l}-13.28^{* * *} \\
(-3.51)\end{array}$ & $\begin{array}{l}-13.03^{* * *} \\
(-3.43)\end{array}$ & $\begin{array}{l}-13.47^{* * *} \\
(-3.52)\end{array}$ & $\begin{array}{l}-13.97^{* * *} \\
(-3.68)\end{array}$ \\
\hline Liquidity & $\begin{array}{l}0.682^{* * *} \\
(4.14)\end{array}$ & $\begin{array}{l}0.645^{* * *} \\
(4.39)\end{array}$ & $\begin{array}{l}0.684^{* * *} \\
(4.03)\end{array}$ & $\begin{array}{l}0.640^{* * * *} \\
(4.80)\end{array}$ & $\begin{array}{l}0.683^{* * *} \\
(4.12)\end{array}$ & $\begin{array}{l}0.675^{* * *} \\
(4.33)\end{array}$ & $\begin{array}{l}0.691 * * * \\
(3.51)\end{array}$ & $\begin{array}{l}0.648^{* * * *} \\
(3.99)\end{array}$ \\
\hline Sensitivity & $\begin{array}{l}1.211^{*} \\
(1.80)\end{array}$ & $\begin{array}{l}1.092^{*} \\
(1.66)\end{array}$ & $\begin{array}{l}1.333^{*} \\
(1.94)\end{array}$ & $\begin{array}{l}1.576^{* * *} \\
(2.38)\end{array}$ & $\begin{array}{l}1.197^{*} \\
(1.75)\end{array}$ & $\begin{array}{l}1.268^{*} \\
(1.89)\end{array}$ & $\begin{array}{r}1.135 \\
(1.50)\end{array}$ & $\begin{array}{l}1.316^{*} \\
(1.83)\end{array}$ \\
\hline GDP & $\begin{array}{l}-12.40^{* * *} \\
(-5.53)\end{array}$ & $\begin{array}{l}-11.98^{* * *} \\
(-5.27)\end{array}$ & $\begin{array}{l}-12.16^{* * *} \\
(-5.40)\end{array}$ & $\begin{array}{l}-11.65^{* * *} \\
(-5.13)\end{array}$ & $\begin{array}{l}-12.45^{* * *} \\
(-5.48)\end{array}$ & $\begin{array}{l}-11.86^{* * *} \\
(-4.78)\end{array}$ & $\begin{array}{l}-12.92^{* * * *} \\
(-5.69)\end{array}$ & $\begin{array}{l}-12.36^{* * *} \\
(-5.40)\end{array}$ \\
\hline Size & & $\begin{array}{l}0.0800 \\
(1.39)\end{array}$ & & & & & & \\
\hline Business Age & & & $\begin{array}{l}0.00391 \\
(1.51)\end{array}$ & & & & & \\
\hline Ownership & & & & $\begin{array}{l}1.186^{* * * *} \\
(2.56)\end{array}$ & & & & $\begin{array}{l}1.407^{* * * *} \\
(2.87)^{2}\end{array}$ \\
\hline Bank Holding & & & & & $\begin{array}{l}-0.0214 \\
(-0.12)\end{array}$ & & & \\
\hline GFC & & & & & & $\begin{array}{c}0.107 \\
(0.51)\end{array}$ & & \\
\hline Supervisor: FED & & & & & & & $\begin{array}{l}0.0885 \\
(0.30)\end{array}$ & $\begin{array}{l}0.0749 \\
(0.25)\end{array}$ \\
\hline Supervisor: OCC & & & & & & & $\begin{array}{l}0.654^{* * *} \\
(3.10)\end{array}$ & $\begin{array}{l}0.657^{* * * *} \\
(3.12)\end{array}$ \\
\hline Supervisor: OTS & & & & & & & $\begin{array}{c}0.181 \\
(0.75)\end{array}$ & $\begin{array}{l}0.503^{* * *} \\
(2.01)\end{array}$ \\
\hline Constant & $\begin{array}{l}-2.739 * * * \\
(-7.41)\end{array}$ & $\begin{array}{l}-3.678^{* * *} \\
(-4.78)\end{array}$ & $\begin{array}{l}-3.001^{* * * *} \\
(-7.54)\end{array}$ & $\begin{array}{l}-3.932 * * * \\
(-6.69)\end{array}$ & $\begin{array}{l}-2.726^{* * *} \\
(-7.08)\end{array}$ & $\begin{array}{l}-2.781 * * * \\
(-7.39)\end{array}$ & $\begin{array}{l}-2.975 * * * \\
(-7.62)\end{array}$ & $\begin{array}{l}-4.429 * * * \\
(-7.04)\end{array}$ \\
\hline Total Obs. & 710217 & 710217 & 710217 & 710217 & 710217 & 710217 & 710217 & 710217 \\
\hline \# of Banks & 16188 & 16188 & 16188 & 16188 & 16188 & 16188 & 16188 & 16188 \\
\hline Log Likelihood & -792.8 & -791.9 & -791.0 & -788.5 & -792.8 & -792.7 & -788.2 & -783.0 \\
\hline AIC & 1603.6 & 1603.7 & 1602.1 & 1597.0 & 1605.6 & 1605.4 & 1600.4 & 1592.0 \\
\hline BIC & 1706.9 & 1718.4 & 1716.8 & 1711.7 & 1720.3 & 1720.1 & 1738.1 & 1741.1 \\
\hline
\end{tabular}

Standardized beta coefficients; $t$ statistics in parentheses

$* p<0.05, * * p<0.01, * * p<0.001$

may be important. Hau, Langfield, and Marqués-Ibañez (2012) suggest that rating agencies systematically underestimate the relative risks of larger banks, in part because they feel they are too-big-to-fail, but also because those banks can exert disproportionate influence on the raters. While we use what are apparently 
unbiased measures of the state of the bank, it is possible that the authorities may not react unambiguously to the sign of fragility irrespective of size of the bank.

Second, we test the hypothesis that the age of banks might have an influence on their likelihood of distress. The rationale is that de novo banks ${ }^{46}$ might have an incentive to run their banks at low margins to gain a foot in the market or many simply take greater risks, revealed in CAMELS (DeYoung, 2003). Therefore, younger banks might be more fragile. Again the data do not support this hypothesis. Business age has no significant influence on the probability of failure.

Although the business age has no additional explanatory power, it might be interesting to investigate whether the characteristics of distressed de novo banks differ from established distressed banks. We break down our sample into de novo banks and established banks with 49 failures and 504 failures, respectively. The results are given in Table 13. Perhaps the most interesting consequence is that the CAMELS model becomes much better determined. All six elements (and GDP) have the correct signs and are significant at least the $5 \%$ level ${ }^{47}$. This implies that de novo banks are fogging the results by being much less easily explained. De novo bank failures appear to have just two indicators with any substantial significance. Capital has the strongest influence, interestingly enough with a very similar coefficient to the rest of bank failures, while earnings are also important. These indicators reflect the challenges of young banks. Their business model tends to be riskier and has a lower profitability than established banks ${ }^{48}$.

Thirdly, there are two ways in which the form of ownership might have an influence on fragility. First of all, joint stock banks may be more likely to fail than mutual institutions, if, for example, they are engaged in riskier business activities. We there insert a dummy variable to distinguish joint stock banks from mutual institutions (labelled ownership in Table 12). Our data suggest that this relationship may hold and joint stock institutions do indeed have a greater likelihood of failure.

However, there is a second aspect of ownership that is prima facie also important. Banks are often owned by bank holding companies and this can be expected to decrease their chance of failure as the holding company can act as a source of strength. The affiliation to a holding company may have also benefits for the individual banks because of access to better diversification or better funding opportunities. Furthermore, the opportunity to acquire better operating systems

46 We retain the definition of the Federal Reserve System (FED) (1991) that a de novo bank is a bank that "has been in operation for five years or less".

47 The most notable effect is that the indicator for sensitivity to market risk for established banks is now clearly significant. Therefore, the insignificance of the total sample seems to be due to the presence of de novo banks, where the sign of the sensitivity coefficient is opposite.

48 Dividing the sample leads to a small improvement in predictive accuracy. Whereas the full sample leverage logit model classified $80 \%$ of all distress and failure events of financial institutions correctly, the sub-samples of de novo banks and established banks classify $90 \%$ and $80 \%$ respectively of the events correctly. 
Table 13: De Novo Banks

\begin{tabular}{l|c|c|c}
\hline & All Banks & De Novo Banks & Established Banks \\
\hline Capital (LEV) & $-127.7^{* * *}$ & $-117.9^{* * *}$ & $-126.8^{* * *}$ \\
& $(-22.97)$ & $(-4.54)$ & $22.15)$ \\
\hline Asset & $22.89^{* * *}$ & 9.986 & $(9.54)$ \\
& $(9.40)$ & $(1.30)$ & $0.105^{* * *}$ \\
\hline Management & $0.104^{* * *}$ & 0.361 & $(1.85)$ \\
& $(1.98)$ & $(1.49)$ & $-13.58^{* * *}$ \\
\hline Earnings & $-13.27^{* * *}$ & $-34.16^{* * *}$ & $(-3.44)$ \\
\hline Liquidity & $(-3.51)$ & $(-2.05)$ & $0.658^{* * *}$ \\
& $0.682^{* * *}$ & 0.325 & $(4.07)$ \\
\hline Sensitivity & $(4.14)$ & $(0.35)$ & $2.005^{* * *}$ \\
& $1.210^{* *}$ & -0.658 & $-11.35^{* * *}$ \\
\hline GDP & $(1.80)$ & $(-0.26)$ & $(-4.84)$ \\
\hline Total Observations & $-12.41^{* * *}$ & -9.260 & 678798 \\
\hline \# of Bank Failures & $(-5.53)$ & $(-0.88)$ & 504 \\
\hline Log Likelihood & 710217 & 31419 & -734.8 \\
\hline AIC & 553 & 49 & 1487.7 \\
\hline BIC & -792.8 & -49.0 & 1590.5 \\
\hline
\end{tabular}

$t$ statistics in parentheses

$* p<0.05, * * p<0.01, * * * p<0.001$

and management practices should be greater. We would therefore expect a negative coefficient. Our data offer no support for this.

We also consider whether the global financial crisis from Q3/2007 onwards differs from the rest of the dataset and whether it reflects unusual behaviour as there were so many failures in this period. Again, our model offers no support for this hypothesis and suggests that the GFC is not different from other periods. This corroborates the findings in Section 4. We try varying the date for the onset of the crisis but do not find a clear break point. We tried interacting this GFC dummy with the other coefficients in the model in order to test whether any change in behaviour was more comprehensive. Interestingly enough only two variables showed a change in effect: Earnings and Sensitivity, in both cases failures became more responsive to changes in these variables. Sensitivity was rather poorly determined in the sample as a whole and including these shift coefficients clearly helps.

Lastly, the regulatory framework might have an effect. It is not just that regulators may behave differently but they regulate also different sorts of bank. 
Some types of banks may be more exposed to failure than others (Table 3). There is some suggestion of regulatory competition with some regulators pursuing a more laissez-faire approach to gain competitive advantage (Mayes, Nieto and Wall, 2011). FDIC-regulated banks reflect the base scenario. Our data suggest that non-FDIC-regulated banks are more likely to get into distress. FDIC-regulated banks are less exposed to insolvency than banks supervised by the FED, OCC or OTS. OCC-regulated commercial banks are significantly more likely to get into distress. At this stage the explanation is rather speculative. OTS-supervised institutions tend to be more exposed to the property sector but involved in a more conservative range of lending. Hence lighter supervision but exposure to extreme events might be rational. The OCC results are more difficult to explain as those are larger banks.

We therefore investigate the influence of regulatory bodies and different capital measures to banking distress further, by running logit regressions for each regulatory type separately (Table 14) and examining their forecasting abilities (Table 15). The results suggest that the leverage ratio is more helpful for FRB-supervised banks. The risk-based capital model is more useful for FDIC and OCC-supervised banks. A rationale might be that FRB-supervised banks (bank holding companies) are more complex than commercial banks and the leverage ratio is a more robust indicator for complex banks. In consequence this finding reveals that simple rules such as the leverage ratio seem to be most effective in rather complex environments. This would bear out the comments of Haldane and Madouros (2012) that it is the supervision of complex institutions that would benefit most from simpler indicators. The risk-based capital seems to be more striking for commercial banks. The tables also reveal that OTS-supervised banks seem to be different.

Finally, we include all of the extra significant influence categories (ownership and supervisor type) in model (8). The base scenario represents FDIC-supervised non-stock banks. All the variables still have the expected sign and the significance of the individual parameters remains similar, however the management variable is only significant at the $10 \%$ level. OCC supervision may be a proxy for size, since our continuous measure does not capture this simple division - but is still the counter-intuitive sign.

These tests therefore suggest that we have a quite robust and stable formulation for the CAMELS model, although it is the capital adequacy variable that is the main and resilient driver. Omitting the AMELS variables still gives good predictability, as also noted by Haldane and Madouros (2012). The goodness of fit and prediction accuracy for model (8) are similar to model (1), implying that this base model offers a reasonable explanation as it stands. 
Table 14: Regulatory Types - Logit Estimation

\begin{tabular}{|c|c|c|c|c|c|c|c|c|}
\hline & FDIC & FRB & OCC & OTS & FDIC & FRB & OCC & OTS \\
\hline Capital (LEV) & $\begin{array}{l}-146.7^{* * *} \\
(-15.11)\end{array}$ & $\begin{array}{l}-237.1^{* * *} \\
(-6.12)\end{array}$ & $\begin{array}{l}-103.2^{* * *} \\
(-11.49)\end{array}$ & $\begin{array}{l}-99.24^{* * *} \\
(-8.17)\end{array}$ & & & & \\
\hline Capital (RBC) & & & & & $\begin{array}{l}-177.3^{* * *} \\
(-16.31)\end{array}$ & $\begin{array}{l}-205.2^{* * *} \\
(-6.53)\end{array}$ & $\begin{array}{l}-128.6^{* * *} \\
(-11.86)\end{array}$ & $\begin{array}{l}-107.1^{* * *} \\
(-8.30)\end{array}$ \\
\hline Assets & $\begin{array}{l}26.08^{* * *} \\
(6.39)\end{array}$ & $\begin{array}{l}21.42^{*} \\
(1.69)\end{array}$ & $\begin{array}{l}19.04^{* * *} \\
(4.11)\end{array}$ & $\begin{array}{l}27.17^{* * *} \\
(4.64)\end{array}$ & $\begin{array}{l}31.14^{* * *} \\
(8.17)\end{array}$ & $\begin{array}{l}34.61^{* * *} \\
(4.10)\end{array}$ & $\begin{array}{l}23.36^{* * *} \\
(4.49)\end{array}$ & $\begin{array}{l}28.18^{* * *} \\
(5.49)\end{array}$ \\
\hline Management & $\begin{array}{l}0.0217 \\
(0.11)\end{array}$ & $\begin{array}{l}0.0673 \\
(0.08)\end{array}$ & $\begin{array}{l}0.612^{* *} \\
(2.37)\end{array}$ & $\begin{array}{l}0.329^{* *} \\
(2.34)\end{array}$ & $\begin{array}{l}-0.0664^{*} \\
(-1.66)\end{array}$ & $\begin{array}{l}-0.577 \\
(-1.39)\end{array}$ & $\begin{array}{l}0.700^{* *} \\
(2.50)\end{array}$ & $\begin{array}{l}0.348^{*} \\
(1.76)\end{array}$ \\
\hline Earnings & $\begin{array}{l}-12.12^{* *} \\
(-2.01)\end{array}$ & $\begin{array}{l}-9.724 \\
(-0.52)\end{array}$ & $\begin{array}{l}-17.30^{* *} \\
(-2.43)\end{array}$ & $\begin{array}{l}-10.25 \\
(-1.09)\end{array}$ & $\begin{array}{l}-7.963 \\
(-1.30)\end{array}$ & $\begin{array}{l}-22.23 \\
(-1.43)\end{array}$ & $\begin{array}{l}-16.62 * * \\
(-2.08)\end{array}$ & $\begin{array}{l}-19.55^{* *} \\
(-2.02)\end{array}$ \\
\hline Liquidity & $\begin{array}{c}0.550 \\
(1.26)\end{array}$ & $\begin{array}{l}-3.951^{*} \\
(-1.90)\end{array}$ & $\begin{array}{l}0.467^{* *} \\
(2.48)\end{array}$ & $\begin{array}{l}1.653^{* * * *} \\
(2.73)\end{array}$ & $\begin{array}{l}1.062^{* * *} \\
(2.03)\end{array}$ & $\begin{array}{r}-2.347 \\
(-1.35)\end{array}$ & $\begin{array}{c}0.689 \\
(1.47)\end{array}$ & $\begin{array}{l}1.643^{* * * *} \\
(2.79)\end{array}$ \\
\hline Sensitivity & $\begin{array}{l}2.464^{*} \\
(1.72)\end{array}$ & $\begin{array}{l}6.099^{*} \\
(1.70)\end{array}$ & $\begin{array}{l}2.829^{* *} \\
(2.35)\end{array}$ & $\begin{array}{l}-3.358^{*} \\
(-1.65)\end{array}$ & $\begin{array}{c}1.799 \\
(1.21)\end{array}$ & $\begin{array}{l}-0.0315 \\
(-0.01)\end{array}$ & $\begin{array}{l}2.166 \\
(1.33)\end{array}$ & $\begin{array}{l}-3.434^{*} \\
(-1.74)\end{array}$ \\
\hline GDP & $\begin{array}{l}-9.987 * * * \\
(-2.84)\end{array}$ & $\begin{array}{r}-6.449 \\
(-0.62)\end{array}$ & $\begin{array}{l}-17.71^{* * *} \\
(-4.34)\end{array}$ & $\begin{array}{l}-9.987^{* * *} \\
(-2.84)\end{array}$ & $\begin{array}{l}-10.94^{* * *} \\
(-3.00)\end{array}$ & $\begin{array}{c}-9.124 \\
(-0.97)\end{array}$ & $\begin{array}{l}-17.75^{* * *} \\
(-3.84)\end{array}$ & $\begin{array}{l}-17.50^{* * *} \\
(-3.25)\end{array}$ \\
\hline Constant & $\begin{array}{l}-2.530^{* * * *} \\
(-3.46)\end{array}$ & $\begin{array}{l}4.627^{* *} \\
(2.05)\end{array}$ & $\begin{array}{l}-3.582^{* * * *} \\
(-5.92)\end{array}$ & $\begin{array}{l}-4.146^{* * *} \\
(-4.69)\end{array}$ & $\begin{array}{c}0.751 \\
(0.95)\end{array}$ & $\begin{array}{l}5.991^{* *} \\
(2.36)\end{array}$ & $\begin{array}{l}-1.153 \\
(-1.45)\end{array}$ & $\begin{array}{l}-2.654^{* * *} \\
(-2.68)\end{array}$ \\
\hline Total Obs. & 405839 & 68413 & 160996 & 74969 & 405839 & 68413 & 160996 & 74969 \\
\hline \# of Banks & 9724 & 2036 & 4903 & 2219 & 9724 & 2036 & 4903 & 2219 \\
\hline Log Likelihood & -324.0 & -43.3 & -230.9 & -160.8 & -310.4 & -60.1 & -211.2 & -170.0 \\
\hline AIC & 666.1 & 104.6 & 479.7 & 339.7 & 638.8 & 138.2 & 440.4 & 358.0 \\
\hline BIC & 764.3 & 186.8 & 569.6 & 422.7 & 737.0 & 220.4 & 530.3 & 441.1 \\
\hline
\end{tabular}

Standardized beta coefficients; $t$ statistics in parentheses

$* p<0.05, * * p<0.01, * * * 0<0.001$

Table 15: Regulatory Types - Forecasting Ability

\begin{tabular}{|c|c|c|c|c|c|}
\hline \multirow[b]{2}{*}{ Leverage Model } & \multicolumn{2}{|c|}{ Distress } & \multirow{2}{*}{$\begin{array}{c}\text { Risk-Based } \\
\text { Capital Model }\end{array}$} & \multicolumn{2}{|c|}{ Distress } \\
\hline & $\begin{array}{l}\text { correctly } \\
\text { detected }\end{array}$ & falsely detected & & $\begin{array}{l}\text { correctly } \\
\text { detected }\end{array}$ & falsely detected \\
\hline FDIC & $85.71 \%$ & - & FDIC & $86.98 \%$ & - \\
\hline FRB & $89.29 \%$ & - & FRB & $82.14 \%$ & - \\
\hline OCC & $71.55 \%$ & - & OCC & $74.14 \%$ & - \\
\hline OTS & $62.12 \%$ & - & OTS & $59.09 \%$ & - \\
\hline
\end{tabular}




\section{CONCLUSION AND POLICY IMPLICATIONS}

In this paper we apply the well-established CAMELS method to predict bank distress for the last 20 years in the US. We find that all the traditional CAMELS factors used previously are robust and stable while explaining recent banking failures accurately. Concentration just on capital adequacy, for example, while capturing most occurrences, would miss many of the problem cases. Further, we investigate which traditional indicators are more efficient in predicting distress and failure In exploring the appropriate measurement of capital we find that risk-weighted measures do not outperform a simple leverage ratio ${ }^{49}$. This does not imply that there should be any reduction in the use of risk-weighted measures in deciding how much capital a bank should hold in normal times, but that when things start to go wrong, a simple leverage ratio, which is transparent and more difficult to manipulate, would be the better indicator of problems ${ }^{50}$. We look for a range of possible improvements to the basic CAMELS formulation but find just two to have any noticeable effect. The failure characteristics of de novo banks seem to be somewhat different and can be explained by just two factors (capital adequacy and earning power). We also find that the leverage ratio works best for complex banks. Additional parameters do not offer any further explanation. Further, we investigate the predictive quality of our model and find that the logit leverage specification performs well in forecasting bank distress up to two periods ahead.

The evidence in this paper suggests that the traditional types of early warning model of bank distress available before the global financial crisis would have worked quite well during the crisis. Although the parameters of the models do change when the much larger number of failures during the GFC are added to the data set and the forecasting ability of the models improves, these improvements are relatively small.

As a result we conclude that Basel III is correct in including the leverage ratio in its requirements for improved supervision and that supervisors would be wise to adopt it. It is of course possible that the US is unusual in this regard and future work needs to be undertaken elsewhere - on European data for example - to make sure that it is reasonable to apply the implications elsewhere. However, on the basis of our estimates, if anything, it might be that higher prominence is warranted for the leverage ratio in the Basel framework and perhaps the trigger value should be somewhat harsher. At the present, it is likely to act rather more as a backstop to the risk-weighted measures. The better performance of the

When a shorter sample period is used the leverage ratio tends to perform a little better.

Blum (2007) shows in a simple model why having a leverage ratio requirement in addition to risk-sensitive requirements increases social welfare if the costs of bank failure and the fraction of risky banks is high and the cost of capital low. 
leverage ratio for more complex banks also validates our finding that simpler rules seem to work better in complex environments. Further, if we follow the reasoning of Haldane and Madouros (2012) then the simple leverage ratio would be the preferred indicator when crisis threatens ${ }^{51}$. No doubt other estimation methods could be used, such as data envelopment analysis but our results seem sufficiently clear that we would not expect them to be totally overturned.

\section{REFERENCES}

Abrams, B. A. and Huang, C. J., 1987, "Predicting Bank Failures: The Role of Structure in Affecting Recent Failure Experiences in the USA", Applied Economics, 19(10), 1291-1302.

Alam, P., Booth, D., Lee, K. and Thordarson, T., 2000, “The Use of Fuzzy Clustering Algorithm and Self-Organizing Neural Networks for Identifying Potentially Failing Banks: An Experimental Study", Expert Systems with Applications, 18(3), 185-199.

Altman, E. I., 1977, "Predicting Performance in the Savings and Loan Association Industry", Journal of Monetary Economics, 3(4), 443-466.

ANDERSEN, H., 2008, Failure Prediction of Norwegian Banks: A Logit Approach, Norges Bank Working Paper - No. 2008/2.

ARenA, M., 2008, "Bank Failures and Bank Fundamentals: A Comparative Analysis of Latin America and East Asia During the Nineties Using BankLevel Data", Journal of Banking \& Finance, 32(2), 299-310.

Australian PRUdential RegUlation AUTHORITy (APRA), 2012, Implementing Basel III Capital Reforms in Australia, Response to Submissions.

Avery, R. B. and HANWECK, G. A., 1984, A Dynamic Analysis of Bank Failures, Research Papers in Banking and Financial Economics - No. 74.

Avkiran, N. K. and CaI, L. C., 2012, Predicting Bank Financial Distress Prior to Crises, Working Paper.

AzIZ, M. A. and DAR, H. A., 2006, "Predicting Corporate Bankruptcy: Where We Stand?”, Corporate Governance, 6(1), 18-33.

BARnetT, V. and LewIS, T., 1994, Outliers in Statistical Data, Chichester; New York: Wiley.

\footnotetext{
This point is made in a different way by Demirguc-Kunt, Detragiache, and Merrouche (2010), when they conclude on the basis of an unbalanced sample of 381 large banks from 12 countries that "during the crisis stock returns of large and under-capitalized banks were much more sensitive to leverage ratios as opposed to risk-adjusted capital ratios. This may be because market participants viewed risk-adjusted ratios as much less transparent."
} 
BARR, R., SEIFORD, L. and SIEMS, T., 1993, “An Envelopment-Analysis Approach to Measuring the Managerial Efficiency of Banks”, Annals of Operations Research, 45(1), 1-19.

BARR, R. and SIEMS, T., 1994, Predicting Bank Failure Using DEA to Quantify Management Quality, Financial Industry Studies Working Papers, 94(1).

Barth, J. R., Brumbaugh, R. D., Sauerhaft, D. and Wang, G. H. K., 1985, "Thrift Institution Failures: Causes and Policy Issues", Proceedings, 184216.

BASEl COMMITTEE ON BANKING SUPERVISION (BCBS), 2011, Basel III: A Global Regulatory Framework for More Resilient Banks and Banking Systems, December 2010 (rev. June 2011).

Berg, S. A. and HeXeberg, B., 1994, Early Warning Indicators for Norwegian Banks: A Logit Analysis of the Experiences from the Banking Crisis, Norges Bank Working Paper - No. 1/1994.

Betz, F., Oprica, S., Peltonen, T.A. and SARlin, P., 2013, Predicting Distress in European Banks, ECB Working Paper 1597, October.

Blum, J. M., 2007, Why Basel II May Need a Leverage Ratio Restriction, Swiss National Bank Working Papers 2007-4.

Bongini, P., LAeven, L. and MAjNONI, G., 2002, "How Good Is the Market at Assessing Bank Fragility? A Horse Race between Different Indicators”, Journal of Banking \& Finance, 26(5), 1011-1028.

Campbell, J. Y., Hilscher, J. and Szilagyi, J. A. N., 2008, "In Search of Distress Risk", The Journal of Finance, 63(6), 2899-2939.

ČIHÁK, M., 2007, "SYSTEMIC LOSS: A MEASURE OF FinANCIAL STABILITY” (IN ENGLISH), CZECH JOURNAL OF ECONOMICS AND FINANCE, 57(1-2), 5-26.

Cole, R. A. and Gunther, J., 1995a, “A Camel Rating's Shelf Life”, Federal Reserve Bank of Dallas Review, 13-20.

Cole, R. A. and GunTHER, J., 1995b, "Separating the Likelihood and Timing of Bank Failure", Journal of Banking \& Finance, 19(6), 1073-1089.

Cole, R. A. and GunTHER, J., 1998, "Predicting Bank Failures: A Comparison of on- and Off-Site Monitoring Systems", Journal of Financial Services Research, 13(2), 103-117.

Cole, R. A. and White, L. J., 2012, “Déjà Vu All over Again: The Causes of U.S. Commercial Bank Failures This Time Around", Journal of Financial Services Research, 42(1-2), 5-29.

Collier, C., Forbush, S., Nuxoll, D.A. and O'Keefe, J., 2003, “The SCOR System of Off-Site Monitoring: Its Objectives, Functioning and Performance”, FDIC Banking Review, 15(3), 17-32.

Cox, D. R., 1972, "Regression Models and Life-Tables", Journal of the Royal Statistical Society. Series B (Methodological), 34(2), 187-220. 
Curry, T. J., Elmer, P. J. and Fissel, G. S., 2007, “Equity Market Data, Bank Failures and Market Efficiency", Journal of Economics and Business, 59(6), 536-559.

Curry, T. J., Fissel, G. S. and Elmer, P. J., 2003, “Using Market Information to Help Identify Distressed Institutions: A Regulatory Perspective”, FDIC Banking Review Series, 15(3), 1-16.

DAS, S. and Sy, A. N. R., 2012, How Risky Are Banks' Risk Weighted Assets? Evidence from the Financial Crisis, IMF Working Paper - No. 12/36.

DAVIS, E. P. and KARIM, D., 2008, "Comparing Early Warning Systems for Banking Crises”, Journal of Financial Stability, 4(2), 89-120.

DEMIRGÜÇ-KUNT, A., 1989, “Deposit-Institution Failures: A Review of Empirical Literature", Economic Review(Q IV), 2-18.

DemirgüÇ-Kunt, A. and Detragiache, E., 1998, “The Determinants of Banking Crises in Developing and Developed Countries”, IMF Staff Papers, 45(1), 81-109.

DemirgüÇ-Kunt, A., Detragiache, E. and Merrouche, O., 2010, Bank Capital: Lessons from the Financial Crisis, IMF Working Paper No. $10 / 286$.

DemyanYK, Y. and Hasan, I., 2010, "Financial Crises and Bank Failures: A Review of Prediction Methods", Omega, 38(5), 315-324.

DeYoung, R., 2003, “De Novo Bank Exit”, Journal of Money, Credit, and Banking, 35(5), 711-728.

Estrella, A., PARK, S. and Peristiani, S., 2000, "Capital Ratios as Predictors of Bank Failure", Federal Reserve Bank of New York Economic Policy Review, 6(2), 33-52.

Evens, O., LeOne, A. M., Gill, M. S. and Hilbers, P. L. C., 2000, Macroprudential Indicators of Financial System Soundness, IMF Occasional Paper - No. 192.

FEDERAL RESERVE SYSTEM (FED), 1991, “Application and Supervision Standards for De Novo State Member Banks”, Supervisory Letter - 91/17.

Fethi, M. D. and PASIOURAs, F., 2009, Assessing Bank Performance with Operational Research and Artificial Intelligence Techniques: A Survey, University of Bath (School of Management) - Working Paper No. 2009/02.

FlANNERY, M. J., 1998, “Using Market Information in Prudential Bank Supervision: A Review of the U.S. Empirical Evidence", Journal of Money, Credit and Banking, 30(3), 273-305.

GArciA, G. G. H., 2012, "Missing the Red Flag” in D. G. MAYES and G. E. WOOD (eds.), Reforming the Governance of the Financial Sector, Routledge, Abingdon, forthcoming. 
Gaytán, A. and Johnson, C. A., 2002, A Review of the Literature on Early Warning Systems for Banking Crises, Central Bank of Chile - Working Paper - No. 183.

GonZalez-Hermosillo, B., 1999, "Developing Indicators to Provide Early Warnings of Banking Crises”, Finance and Development, 36(2), 36-39.

Haldane, A. G., 2011, Capital Discipline, Given at the American Economic Association, 9 January, available at

www.bankofengland.co.uk/publications/speeches/2011/speech484.pdf.

Haldane, A. G. and Madouros, V., 2012, The Dog and the Frisbee, Given at the Federal Reserve Bank of Kansas City's 36th economic policy symposium, “The Changing Policy Landscape”, Jackson Hole, Wyoming (31 August 2012), available at http://kansascityfed.org/publicat/sympos/2012/ah.pdf?sm=jh083112-3.

Halling, M. and Hayden, E., 2006, "Bank Failure Prediction: A Two-Step Survival Time Approach”, IFC Bulletin - No. 28, 48-73.

HANC, G., 1998, “The Banking Crises of the 1980s and Early 1990s: Summary and Implications", FDIC Banking Review, 11(1), 1-55.

HANWECK, G. A., 1977, Predicting Bank Failure, FED Research Paper in Banking and Financial Economics - No. 19.

Hardy, D. and PAZARBASIOGLU, C., 1998, Leading Indicators of Banking Crises: Was Asia Different?, IMF Working Paper - No. 98/91.

Harrell Jr., F. E., Califf, R. M., Pryor, D. B., Lee, K. L. and Rosati, R. A., 1982, "Evaluating the Yield of Medical Tests", JAMA: The Journal of the American Medical Association, 247(18), 2543-2546.

Harrell Jr., F. E., LeE, K. L. and MARK, D. B., 1996, “Multivariable Prognostic Models: Issues in Developing Models, Evaluating Assumptions and Adequacy, and Measuring and Reducing Errors”, Statistics in Medicine, 15(4), 361-387.

Hau, H., Langfield, S. and MarquéS-IbaÑeZ, D., 2012, Bank Ratings: What Determines Their Quality?, ECB Working Paper - No. 1484.

Henebry, K. L., 1997, “A Test of the Temporal Stability of Proportional Hazards Models for Predicting Bank Failure", Journal of Financial and Strategic Decisions, 10(3), 1-11.

Hillegeist, S. A., Keating, E. K., Cram, D. P. and Lundstedt, K. G., 2004, "Assessing the Probability of Bankruptcy", Review of Accounting Studies, 9(1), 5-34.

IMF, 2005, The Treatment of Nonperforming Loans, Clarification and Elaboration of Issues Raised by the December 2004 Meeting of the Advisory Expert Group of the Intersecretariat Working Group on National Accounts.

Jagtiani, J. and LemieuX, C., 2001, “Market Discipline Prior to Bank Failure”, Journal of Economics and Business, 53(2-3), 313-324. 
Jin, J. Y., Kanagaretnam, K. and Lobo, G. J., 2011, “Ability of Accounting and Audit Quality Variables to Predict Bank Failure During the Financial Crisis”, Journal of Banking \& Finance, 35(11), 2811-2819.

Joint SHAdow Financial Regulatory COMmitTeE (JSFR), 2011, The Eurozone Crisis: A Roadmap for Urgent and Decisive Action, Statement October 24, 2011.

Jordan, D. J., Rice, D., SANChez, J., Walker, C. and Wort, D. H., 2010, Predicting Bank Failures: Evidence from 2007 to 2010, Working Paper.

JOSE, A. L., 1999, “Using Camels Ratings to Monitor Bank Conditions”, FRBSF Economic Letter - 06/99.

KaO, C. and LiU, S.-T., 2004, "Predicting Bank Performance with Financial Forecasts: A Case of Taiwan Commercial Banks", Journal of Banking \& Finance, 28(10), 2353-2368.

KIEFER, N. M., 1988, “Economic Duration Data and Hazard Functions”, Journal of Economic Literature, 26(2), 646-679.

Kolari, J., Glennon, D., Shin, H. and Caputo, M., 2002, "Predicting Large US Commercial Bank Failures", Journal of Economics and Business, 54(4), 361-387.

Kraft, E. and GalaC, T., 2007, "Deposit Interest Rates, Asset Risk and Bank Failure in Croatia", Journal of Financial Stability, 2(4), 312-336.

Lane, W. R., LoOney, S. W. and Wansley, J. W., 1986, "An Application of the Cox Proportional Hazards Model to Bank Failure", Journal of Banking \& Finance, 10(4), 511-531.

Le Leslé, V. and Avramova, S., 2012, Revisiting Risk-Weighted Assets, IMF Working Paper - No. 12/90.

Logan, A., 2001, The United Kingdom's Small Banks' Crisis of the Early 1990s: What Were the Leading Indicators of Failure?, Bank of England Working Paper - No. 139.

MÄnNASOO, K. and MAYES, D. G., 2005, Investigating the Early Signals of Banking Sector Vulnerabilities in Central and East European Emerging Markets, Working Paper of Eesti Pank - No. 8/2005.

MÄNNASOO, K. and MAYES, D. G., 2009, "Explaining Bank Distress in Eastern European Transition Economies", Journal of Banking \& Finance, 33(2), 244-253.

Mariathasan, M. and Merrouche, O., 2012, The Manipulation of Basel RiskWeights. Evidence from 2007-10, University of Oxford, Department of Economics Discussion Paper - No. 621.

MartiN, D., 1977, "Early Warning of Bank Failure: A Logit Regression Approach", Journal of Banking \& Finance, 1(3), 249-276.

Mayes, D. G., NieTo, M. J. and Wall, L. D., 2011, Creating an EU-Level Supervisor for Cross-Border Banking Groups: Issues Raised by the U.S. 
Experience with Dual Banking, Federal Reserve Bank of Atlanta - Working Paper - No. 2011/06.

Mayes, D. G. and Wood, G. E., 2009, "The Northern Rock Crisis in the UK" in M. BALling, F. BRUNi and D.T. LLEWELLYN (eds.), The Failure of Northern Rock - a Multidimensional Case Study, SUERF Study 2009/1.

McCulloch, W. and PITTS, W., 1943, "A Logical Calculus of the Ideas Immanent in Nervous Activity", Bulletin of Mathematical Biology, 5(4), 115-133.

MeYer, P. A. and PIFER, H. W., 1970, "Prediction of Bank Failures", Journal of Finance, 25(4), 853-868.

ODOM, M. D. and SHARDA, R., 1990, A Neural Network Model for Bankruptcy Prediction, IJCNN International Joint Conference on Neural Networks (San Diego, CA), 2, 163-168.

OHLson, J. A., 1980, "Financial Ratios and the Probabilistic Prediction of Bankruptcy”, Journal of Accounting Research, 18(1), 109-131.

Pantalone, C. C. and Platt, M. B., 1987, "Predicting Commercial Bank Failure since Deregulation", New England Economic Review (Jul), 37-47.

PETTWAy, R. H., 1980, "Potential Insolvency, Market Efficiency, and Bank Regulation of Large Commercial Banks", The Journal of Financial and Quantitative Analysis, 15(1), 219-236.

Poghosyan, T. and ČIHÁK, M., 2009, Distress in European Banks: An Analysis Based on a New Dataset, IMF Working Paper - No. 09/9.

Ravi Kumar, P. and Ravi, V., 2007, "Bankruptcy Prediction in Banks and Firms Via Statistical and Intelligent Techniques - a Review", European Journal of Operational Research, 180(1), 1-28.

RESERVE BANK OF NEW ZEALAND (RBNZ), 2011, Implementation of Basel III Capital Adequacy Requirements in New Zealand, Consultation Paper November 2011.

SAHAJWALA, R. and VAN DEN BERGH, P., 2004, Supervisory Risk Assessment and Early Warning Systems, BCBS - Working Paper - No. 4.

SAlChenberger, L. M., CinAR, E. M. and LASH, N. A., 1992, "Neural Networks: A New Tool for Predicting Thrift Failures”, Decision Sciences, 23(4), 899-916.

Shadow FinAnCial Regulatory COMmitTeE (SFRC), 2012, Alternatives to the Proposed Risk-Based Bank Capital Standards, Shadow Financial Regulatory Committee Statement - February 13, 2012.

SHIN, H. S., 2009, “Reflections on Northern Rock: The Bank Run That Heralded the Global Financial Crisis", Journal of Economic Perspectives, 23(1), 101119.

SINKEY, J. F., 1975, “A Multivariate Statistical Analysis of the Characteristics of Problem Banks”, Journal of Finance, 30(1), 21-36. 
Swicegood, P. and Clark, J. A., 2001, "Off-Site Monitoring Systems for Predicting Bank Underperformance: A Comparison of Neural Networks, Discriminant Analysis, and Professional Human Judgment", Intelligent Systems in Accounting, Finance \& Management, 10(3), 169-186.

TAM, K. Y. and KiAng, M. Y., 1990, "Predicting Bank Failures: A Neural Network Approach”, Applied Artificial Intelligence, 4(4), 265-282.

TAM, K. Y. and KIANG, M. Y., 1992, "Managerial Applications of Neural Networks: The Case of Bank Failure Predictions", Management Science, 38(7), 926-947.

TAtom, J. and Houston, R., 2011, Predicting Failure in the Commercial Banking Industry, Networks Financial Institute Working Paper No. 2011/27.

Thomson, J. B., 1991, "Predicting Bank Failures in the 1980s", Economic Review - Q I, 9-20.

Tung, W. L., Quek, C. and Cheng, P., 2004, "Genso-Ews: A Novel NeuralFuzzy Based Early Warning System for Predicting Bank Failures" [Comparative Study], Neural Networks, 17(4), 567-587.

Whalen, G., 1991, “A Proportional Hazards Model of Bank Failure: An Examination of Its Usefulness as an Early Warning Tool", Economic Review(Q I), 21-31.

WheElock, D. C. and Wilson, P. W., 2000, "Why Do Banks Disappear? The Determinants of U.S. Bank Failures and Acquisitions", Review of Economics and Statistics, 82(1), 127-138.

Worrell, D., 2004, Quantitative Assessment of the Financial Sector: An Integrated Approach, IMF Working Paper - No. 04/153. 


\section{YeARS OF MONEY AND FINANCE - LESSONS AND CHALLENGES}

SUERF commemorates its 50th anniversary with a special volume entitled "50 years of Money and Finance: Lessons and Challenges", published by Larcier. The researchers who have contributed to the volume were asked to look the monetary and financial history of the last 50 years, and to summarise the most important trends and experiences and to then draw conclusions for the future. They were asked to identify the main trends in international financial markets, in global and European macroeconomic (im)balances, in European financial integration, in central banking, in banking and securities markets, in financial innovation and in the origins and handling of financial crises. Path-breaking events, politicial decisions and relevant outstanding research contributions in the field since the early 1960s all feature significantly. Edited by Morten Balling and Ernest Gnan, with a foreword by Christian Noyer, preface by Urs Birchler and an introduction by the editors, and concluding with a timeline of the major events of the last fifty years, the book consists of the following chapters:

- Global and European Monetary Arrangements: from Bretton Woods to EMU

Niels THYGESEN

- Global and Euro Imbalances: China and Germany

Guonan MA and Robert N. MCCAULEY

- Is Monetary Policy a Science? The Interaction of Theory and Practice over the Last 50 Years

William R. WHITE

- Unconventional Monetary Policy of the ECB during the Financial Crisis: an Assessment and New Evidence

Christiaan PatTiPeilohy, Jan Willem VAn den End, Mostafa TABbae, Jon FROST and Jakob DE HAAN

- The development of financial markets and financial theory: 50 years of interaction

Morten BALLING and Ernest GNAN

- Integration versus Interdependence and Complexity in Global Trade and Finance in the Post-War Period

Paul AtKinson, Adrian Blundell-Wignall and Caroline Roulet

- From National towards European/Global Financial Regulation

Charles A.E. GOODHART

- The Evolution of Financial Supervision: the Continuing Search for the Holy

Grail

Donato MASCIANDARO and Marc QUINTYN 
- $\quad$ Fifty Years in the Evolution of Bank Business Models David T. LLEWELLYN

- Performance in European Banking: Productivity, Profitability and Employment Trends

Philip MOLYNEUX

- $\quad$ Shadow Banking and New Lending Channels - Past and Future Patricia JACKSON

- $\quad$ The 2007- Financial Crisis - a EURO-pean Perspective Juan AYUSO and Roberto BLANCO

- The Effects of Derivatives on Underlying Financial Markets: Equity Options, Commodity Derivatives and Credit Default Swaps William ARrATA, Alejandro BERNALES and Virginie COUDERT www.suerf.org/50yearsofmoneyandfinance 


\section{SUERF - SOCIÉTÉ UNIVERSITAIRE EUROPÉENNE DE RECHERCHES FINANCIÈRES}

SUERF is incorporated in France as a non-profit-making Association. It was founded in 1963 as a European-wide forum with the aim of bringing together professionals from both the practitioner and academic sides of finance who have an interest in the working of financial markets, institutions and systems, and the conduct of monetary and regulatory policy. SUERF is a network association of central bankers, bankers and other practitioners in the financial sector, and academics with the purpose of analysing and understanding European financial markets, institutions and systems, and the conduct of regulation and monetary policy. It organises regular Colloquia, lectures and seminars and each year publishes several analytical studies in the form of SUERF Studies.

SUERF has its full-time permanent Executive Office and Secretariat located at the Austrian National Bank in Vienna. It is financed by annual corporate, personal and academic institution membership fees. Corporate membership currently includes major European financial institutions and Central Banks. SUERF is strongly supported by Central Banks in Europe and its membership comprises most of Europe's Central Banks (including the Bank for International Settlements and the European Central Bank), banks, other financial institutions and academics.

\section{SUERF STUDIES}

\section{7-2011}

For details of SUERF Studies published prior to 2012 (Nos. 1 to 22 and 2003/12011/5) please consult the SUERF website at www.suerf.org/suerfstudies.

\section{2}

2012/1 New Paradigms in Monetary Theory and Policy?, edited by Morten Balling and David T. Llewellyn, Vienna 2012, ISBN 978-3-90210961-3

2012/2 New Paradigms in Banking, Financial Markets and Regulations?, edited by Morten Balling, Frank Lierman, Freddy Van den Spiegel, Rym Ayadi and David T. Llewellyn, Vienna 2012, ISBN 978-39021-62-0 
2012/3 Future Risks and Fragilities for Financial Stability, edited by David T. Llewellyn and Richard Reid, Vienna 2012, ISBN 978-3-90210963-7

2012/4 The ESRB at 1, edited by Ernest Gnan, Stefan Gerlach and Jens Ulbrich, Vienna, 2012, ISBN 978-3-9021-0964-4

2012/5 Developing Distress Resolution Procedures for Financial Institutions, Clas Wihlborg, Vienna 2012, ISBN 978-3-9021-0965-1

2013

2013/1 The Interaction of Political, Fiscal and Financial Stability: Lessons from the Crisis, edited by Ernest Gnan, Vienna 2013, ISBN 978-3902109-66-8

2013/2 States, Banks and the Financing of the Economy: Fiscal Policy and Sovereign Risk Perspectives, edited by Morten Balling, Peter Egger and Ernest Gnan, Vienna 2013, ISBN 978-3-902109-67-5

2013/3 States, Bankings and the Financing of the Economy: Monetary Policy and Regualtory Perspective, edited by Morten Balling, Ernest Gnan and Patricia Jackson, Vienna 2013, ISBN 978-3-902109-68-2

2013/4 Property Prices and Real Estate Financing in a Turbulent World, edited by Morten Balling and Jesper Berg, Vienna 2013, ISBN 978 3-902109-70-5

2013/5 The Future of Sovereign Borrowing in Europe, edited by Morten Balling, Ernest Gnan and Johannes Holler, Vienna 2013, ISBN 9783-902109-71-2 